Magdalena Starega

Europejskie Centrum Solidarności, Gdańsk

ORCID: 0000-0002-5583-2600

\title{
Przekształcenia gdańskich obiektów zabytkowych w pierwszej połowie XIX w. w kontekście rodzącej się myśli konserwatorskiej
}

DOI: https://doi.org/10.26881/porta.2018.17.03

Pierwsza połowa XIX w. to okres, który przyniósł znaczące zmiany w postrzeganiu wartości obiektów zabytkowych. Rodziła się wówczas świadomość ich znaczenia zarówno pod względem historycznym, jak i artystycznym ${ }^{1}$. Proces ewolucji stosunku do zabytków uwidocznił się w zmianach na poziomie administracyjno-prawnym, ale także w powstawaniu oddolnych inicjatyw społecznych, w których do głosu dochodzili przedstawiciele lokalnej inteligencji ${ }^{2}$.

Więcej o ewolucji niemieckiej myśli konserwatorskiej w XIX w. zob. Jerzy Frycz, Restauracja i konserwacja zabytków architektury w Polsce w latach 1795-1918, Warszawa 1975; Christofer Herrmann, Andrzej Rzempołuch, Ermländische Ansichten: Ferdinand von Quast und die Anfänge der Denkmalpflege in Preußen und Ermland [Ausstellungskatalog], Potsdam 27.04.-2.07.2006, Olsztyn 6.09.-31.10.2006 = Widoki $z$ Warmii: Ferdynand von Quast i poczatki konserwatorstwa zabytków w Prusach i na Warmii [katalog wystawy], Potsdam 27.04.-2.07.2006, Olsztyn 6.09.-31.10.2006, Olsztyn 2006; Janusz Opaska, U źródeł ochrony zabytków: rozwój systemowego konserwatorstwa w Niemczech w początkach XIX w., „Ochrona Zabytków” 2010, nr 1-4, s. 199-210; Grzegorz Bukal, Konserwacja zamku w Malborku jako przykład ksztattowania się doktryny konserwatorskiej, „Ochrona Zabytków” 2008, nr 3, s. 91-102; Marian Arszyński, Idea - pamięć - troska. Rola zabytków w przestrzeni społecznej i formy działań na rzecz ich zachowania od starożytności do połowy XX wieku, Malbork 2007, s. 136-183. Zob. także: Acta Borussica. Neue Folge. R. 2, Preußen als Kulturstaat, Abt. 2, Der preußische Kulturstaat in der politischen und sozialen Wirklichkeit, Bd. 4, Geschichte der preussischen Denkmalpflege 1815 bis 1860, Berlin 2013. Na temat ochrony gdańskich zabytków w XIX i pierwszej połowie XX w. zob. Ewa Barylewska-Szymańska, Historia ochrony zabytków architektury w XIX i pierwszych dziesięcioleciach XX w. (do 1945 r.). Zarys problematyki [w:] Rzadzacy i rzadzeni. Władza i społeczeństwo od średniowiecza po współczesność. Materiały konferencji naukowej zorganizowanej przez Muzeum Historyczne Miasta Gdańska i Stowarzyszenie Rajcy Gdańska w dniach 24 października 2014 r., 29-30 maja 2015 r., red. Sylwia Bykowska, Edmund Kizik, Piotr Paluchowski, Gdańsk 2015, s. 123-146; tam także dalsza literatura przedmiotu. Wątki dotyczące przebudowy gdańskich obiektów zostały częściowo poruszone w niedawno opublikowanym obszernym opracowaniu autorstwa Ewy Barylewskiej-Szymańskiej i Zofii Maciakowskiej, Miasto i ludzie u progu nowoczesności. Socjotopografia Gdańska pierwszej połowy XIX wieku (Studia i materiały do dziejów domu gdańskiego, cz. 4), red. Edmund Kizik, Gdańsk-Warszawa 2016.

2 Funkcjonowanie gdańskich stowarzyszeń działających na rzecz zachowania lokalnych zabytków opisała w swoim artykule Ewa Barylewska-Szymańska, Gdańskie i lubeckie stowarzyszenia na rzecz ochrony zabytków w XIX i XX wieku [w:] Studia z historii sztuki i kultury Gdańska i Europy Północnej. Prace poświęcone pamięci Doktor Katarzyny Cieślak, red. Jacek Friedrich, Edmund Kizik, Gdańsk 2003, s. 395-416. 
Za symboliczny początek debaty nad ochroną gdańskich zabytków przyjmuje się rok 1822, kiedy to Heinrich Theodor von Schön (1773-1856), ówczesny nadprezydent prowincji Prusy Zachodnie wyszedł $\mathrm{z}$ inicjatywą sporządzenia ewidencji najcenniejszych zabytków architektury i historii w mieście ${ }^{3}$. Spis miał na celu wyłonienie i objęcie ochroną najważniejszych obiektów. W tym samym czasie podjęto działania związane z zachowaniem gotyckiej fasady kamienicy przy ulicy Chlebnickiej 22 (ob. nr 14), w której ochronę silnie zaangażował się właśnie von Schön. Zakupiona przez króla Fryderyka Wilhelma III elewacja kamienicy została ostatecznie przeniesiona na Wyspę Pawią (Pfaueninsel) w Poczdamie ${ }^{4}$. Dyskusja, jaką w gdańskim środowisku wywołał temat przeniesienia fasady, stanowi milowy krok w gdańskim myśleniu nad zabytkami.

Dwadzieścia lat później, w 1844 r. minister ds. wyznań, oświaty i zdrowia wydał zarządzenie, zgodnie z którym każda zmiana w budynkach uznanych za zabytkowe wymagała zgody władz państwowych ${ }^{5}$. Zarządzenie odnosiło się do całego terytorium Królestwa Prus, nie obejmowało jednak budynków prywatnych. Już rok późnej w Gdańsku objęto spisem i ochroną także niektóre budowle zabytkowe należące do władz wojskowych, np. Dwór Bractwa św. Jerzego, klasztor pofranciszkański, Basztę Białą czy Basztę Jacek.

Bardzo istotną datą dla ochrony pruskich zabytków było powołanie przez króla w 1843 r. radcy budowlanego Ferdinanda von Quasta (1807-1877) na nowo utworzony urząd Królewskiego Konserwatora Zabytków (Konservator der Kunstdenkmäler der preußischen Staaten $)^{6}$. Decyzja ta przyczyniła się do skodyfikowania zasad obchodzenia się z obiektami zabytkowymi oraz całego systemu ochrony na poziomie państwowym. Podczas wieloletniej służby na tym stanowisku von Quast angażował się w sprawy związane z gdańskimi obiektami, np. z kościółem Mariackim czy klasztorem brygidek i brygidianów.

Obok rozwiązań na poziomie administracyjnym wkrótce zaczęły się pojawiać także pierwsze inicjatywy oddolne. W Gdańsku, podobnie jak w innych miastach Prus, w pierwszej połowie XIX w. formowały się stowarzyszenia skupiające osoby zainteresowane sztukami plastycznymi, głównie w wymiarze lokalnym. W 1835 r. malarz i grafik Johann Carl Schultz założył Towarzystwo

3 Erich Volmar, Danzigs Bauwerke und ihre Wiederherstellung, Danzig 1940, s. 24. Zob. także: Barylewska-Szymańska, Historia ochrony zabytków..., s. 123-124.

4 Zagadnienie to doczekało się osobnego opracowania, zob. Edmund Kizik, Małgorzata Omilanowska, Wędrująca kamienica. Kilka uwag o translokacji i skopiowaniu kamienicy gotyckiej przy ulicy Chlebnickiej w Gdańsku w świetle źródeł archiwalnych, „Porta Aurea” 2011, t. 10, s. 80-114. Zob. także: Erich Keyser, Denkmalpflege in Danzig vor hundert Jahren, „Denkmalpflege und Heimatschutz" 1926, nr 28, s. 54-57; idem, Die Baugeschichte der Stadt Danzig, Köln-Wien 1972, s. 454-456; Marian Arszyński, Działalność Karola Fryderyka Schinkla na ziemiach Pomorza $i$ Wielkopolski, „Zapiski Historyczne” 1984, t. 49, nr 3, s. 91-94. Rysunek fasady kamienicy znajduje się w Archiwum Państwowym w Gdańsku [dalej: APG], Akta Miasta Gdańska. Kolekcja planów i map, 1520-1942, sygn. 16/950, Gdańsk, fasada domu przy ulicy Chlebnickiej.

5 Barylewska-Szymańska, Historia ochrony zabytków..., s. 128.

6 Amtsblatt der Königl. Regierung zu Danzig. Jahrgang 1844, Danzig 1844, s. 44. 
Magdalena Sztuk Pięknych (Kunstverein zu Danzig), które organizowało wystawy i wspieStarega rało twórców ${ }^{7}$. Pięć lat później zainicjowano działalność Stowarzyszenia na rzecz Upiększania Gdańska (Verschönerungs-Verein zu Danzig), skupiającego się na estetyzacji przestrzeni miasta ${ }^{8}$. Jednak żadna $\mathrm{z}$ tych organizacji nie zajmowała się bezpośrednio zagadnieniami związanymi z ochroną dawnych budynków. Dopiero około połowy wieku narodziły się inicjatywy społeczne mające na celu zgłębianie historii regionu, a także ochronę zabytków. Pierwszą z nich było powstałe w 1856 r. w Gdańsku Stowarzyszenie na rzecz Zachowania Starodawnych Budowli i Zabytków Sztuki Gdańska (Verein zur Erhaltung der altertümlichen Bauwerke und Kunstdenkmäler Danzigs $)^{9}$. Należeli do niego głównie przedstawiciele lokalnych środowisk inteligenckich z kręgów kulturalno-artystycznych ${ }^{10}$. Z kolei w 1860 r. powołane zostało Gdańskie Stowarzyszenie Architektów (Westpreußischer Architekten- und Ingenieur-Verein zu Danzig), skupiające coraz liczniejszych w mieście przedstawicieli tego zawodu ${ }^{11}$. Działalność tego typu organizacji, mimo że na ogół nie miała bezpośredniego wpływu na ochronę gdańskich zabytków, odgrywała jednak pewną rolę w zakresie szerzenia wiedzy o ich wartości i konieczności zachowania ${ }^{12}$.

Mimo stopniowych zmian zachodzących w stosunku do obiektów zabytkowych wiele gdańskich budowli zniknęło bezpowrotnie w pierwszej połowie XIX w. z krajobrazu miasta. Zlikwidowano wówczas przede wszystkim część średniowiecznych miejskich fortyfikacji, uznanych za nieprzydatne do celów obronnych, a będących - wskutek reform Heinricha Friedricha Karla vom und zum Steina i Karla Augusta von Hardenberga - własnością władz wojskowych. W 1803 r. rozebrano Bramę św. Ducha, następnie Bramę Rybacką

Więcej o dziejach i funkcji Towarzystwa zob. Hans Bernhard Meyer, Hundert Jahre Kunstverein zu Danzig 1835-1935, Danzig 1935. Zob. także: Ewa Barylewska-Szymańska, Johann Carl Schultz i ochrona zabytków w Gdańsku [w:] Portret artysty na nowo odkryty. Johann Carl Schultz (1801-1873) znany i nieznany [katalog wystawy], 7 sierpnia -11 października 2009, red. Justyna Lijka, Malbork 2009, s. 121-142.

8 „Danziger Dampfboot”, 30.11.1841, s. 1052.

9 Zgodnie z przyjętym przez Ewę Barylewską-Szymańską tłumaczeniem, zob. eadem, Gdańskie i lubeckie stowarzyszenia...

10 Więcej o zadaniach stowarzyszenia zob. Statut des Vereins zur Erhaltung der alterthümlichen Bauwerke und Kunstdenkmäler Danzigs, Danzig 1856.

11 Ernst Habermann, Westpreußischer Architekten- und Ingenieur-Verein zu Danzig 1860-1910: Chronik des Vereins zur Feier des 50-jährigen Bestehens, Danzig 1910, s. 3.

12 Najskuteczniejsze w zabiegach o ochronę gdańskich zabytków było Stowarzyszenie na rzecz Zachowania Starodawnych Budowli i Zabytków Sztuki Gdańska, które niejednokrotnie przyczyniło się do zachowania bądź restauracji miejscowych obiektów, zob. Geheimes Staatsarchiv Preußischer Kulturbesitz [dalej: GStA PK], I. HA Rep. 93 B Technische Oberbaudeputation, Nr. 1293, Verwaltung der Baupolizei in Danzig, Bd. 4 (1856-1860), bez paginacji. Szczególnie aktywnym członkiem Stowarzyszenia był jego współzałożyciel, dyrektor Królewskiej Szkoły Sztuk Pięknych, Johann Carl Schultz. Z jego inicjatywy powstało specjalne zarządzenie dotyczące prawa budowlanego, mające przeciwdziałać postępującemu procesowi rozbiórki przedproży i ingerencji w zabytkowe elewacje, zob. Erich Keyser, Die Baugeschichte der Stadt Danzig, KölnWien 1972, s. 457-458. 
(1819, 1827-1828), Bramę ulicy Kotwiczników (1826), Żabią (1828), Szeroką (1831), Grzeszników (1836), przy ulicy Zbytki, przy Dworze Miejskim (1846), a także Basztę Dominikańską $(1848)^{13}$. Rozbiórka dotknęła także część średniowiecznych murów rozgraniczających teren Głównego i Starego Miasta ${ }^{14}$. W latach 1839-1840 rozebrano klasztor dominikanów, a kilka lat później pobliską gotycką część muru znajdującą się przy Baszcie Jacek ${ }^{15}$. Podobny los spotkał klasztor brygidek i brygidianów, na miejscu którego w połowie wieku postawiono obiekty o przeznaczeniu wojskowym. Z kolei nowemu dworcowi przy ulicy Toruńskiej ustąiła miejsca renesansowa brama wraz z fragmentem nowożytnych obwałowań od południa. W wyniku przeprowadzonych rozbiórek pozyskano zdatne do ponownego zagospodarowania działki, co skądinąd było dla Gdańska - w obliczu braku wolnych parcel pod zabudowę w obrębie miejskich fortyfikacji - zjawiskiem niezwykle pożądanym. Na odzyskanych terenach wybudowano obiekty o charakterze militarnym, część działek przeznaczono zaś pod zabudowę mieszkalną lub wykorzystano do poszerzenia istniejących ulic.

Zła sytuacja polityczno-gospodarcza Gdańska w pierwszej połowie XIX w. oraz decyzja władz centralnych o utworzeniu w mieście siedziby pruskiego garnizonu nie sprzyjały realizacji nowych, pozamilitarnych inwestycji budowlanych. Brak wystarczającej ilości środków na nowe budowle skłaniał władze do wykorzystania istniejących obiektów poprzez ich adaptację do nowej funkcji. Przeprowadzane w ten sposób przebudowy były szybkim i tanim sposobem na pozyskanie niezbędnych powierzchni. $\mathrm{W}$ omawianym okresie budynki przekształcano także w wyniku odbudowy ze zniszczeń wojennych lub podczas reparacji wymuszonych złym stanem technicznym. Modyfikacje te nierzadko stanowiły efekt próby „zmodernizowania” obiektu. Stosowano wówczas powszechnie formy klasycystyczne, a później także neogotyckie, co skutkowało czasem wprowadzeniem nowych, obcych względem pierwotnego kształtu budynku cech stylowych. Działania te dosięgły wiele najważniejszych gdańskich zabytków, takich jak kościół Mariacki, Ratusz Głównego Miasta czy Dwór Artusa. I tylko o niewielkiej części tych przekształceń można powiedzieć, że stanowiły próbę świadomych prac restauratorskich.

Do pierwszych ingerencji w kształt gdańskich zabytków doszło zresztą zaraz po zajęciu miasta przez Królestwo Prus. W 1798 r. pruski skarb państwa odkupił od rozwiązanego Bractwa św. Jerzego jego siedzibę. Budynek miał szczególnie reprezentacyjną lokalizację, tuż przy bramie Długoulicznej (Złotej), stanowiącej dawniej element tzw. Traktu Królewskiego. Jeszcze w tym samym roku gotycki

13 Ibidem, s. 436. Część budowli obronnych, które nie zostały rozebrane, przekształcono na cele mieszkalne. W bramach wybijano nowe otwory okienne i komunikacyjne, dostosowując je do potrzeb lokatorów.

14 W Archiwum Państwowym w Gdańsku znajduje się plan z 1832 r. z oznaczonym fragmentem murów, który został przeznaczony do rozbiórki, zob. APG, Akta Miasta Gdańska 1520-1942, Plany i mapy, sygn. 16/15, Gdańsk, Plac Dominikański.

15 Keyser, Die Baugeschichte der Stadt Danzig..., s. 439. 
Magdalena obiekt przebudowano na odwach według projektu budowniczego miejskiego Starega Carla Samuela Helda ${ }^{16}$. W przyziemiu budynku rozplanowano wartownię, kwaterę dla wartowników i areszt, a na pierwszym piętrze - pokój dla wyższych funkcjonariuszy oraz izbę przesłuchań ${ }^{17}$. Znacząca zmiana polegała na dodaniu do zachodniej elewacji budynku zadaszenia, pod którym żołnierze mogliby odbywać wartę. Held rozwiązał ten wymóg funkcjonalny dokładnie w taki sam sposób, jak w wypadku zaprojektowanego wcześniej odwachu przy Targu Rybnym - poprzez dostawienie parterowej kolumnady ${ }^{18}$. Rząd ośmiu kolumn o prostych kapitelach stanowił obcy stylowo aneks, jednak Held skupił się na jego praktycznej stronie, dążąc do maksymalnego uproszczenia formy. Odpowiedni rozstaw podpór, które ze względów funkcjonalnych zostały umieszczone dokładnie na linii podziałów pionowych ceglanej elewacji dworu, wpłynął również na zminimalizowanie wrażenia kontrastu z późnogotycką bryłą, przez co uzyskano bardziej harmonijny efekt (il. 1).

Już w 1809 r. badacz dziejów Gdańska Friedrich Carl Gottlieb von Duisburg tak ocenił stan obiektu: „Mimo że można dostrzec w tym budynku wartości zabytkowe, obecnie zostały one utracone" ${ }^{19}$. W 1832 r. rozebrano sygnaturkę dworu (zwieńczoną figurą św. Jerzego) ze względu na jej zły stan techniczny. Prawdopodobnie w tym samym czasie cebulaste hełmy wieżyczek narożnych i na osiach elewacji budynku zostały zastąpione hełmami o prostej, stożkowej formie (il. 2). O tym, że zabiegi te negatywnie wpłynęły na wygląd obiektu, pisał już w 1834 r. sam Karl Friedrich Schinkel, który wyraził nadzieję na szybkie przywrócenie jego pierwotnego kształtu ${ }^{20}$. Sprawą zainteresował się także król Fryderyk Wilhelm IV, który przeznaczył na odbudowę wieży kwotę 5400 talarów. Mimo pewnego zaawansowania prac przygotowawczych do realizacji przedsięwzięcia nie doszło ${ }^{21}$.

Swoją dawną funkcję utracił także budynek szesnastowiecznego Ratusza Staromiejskiego przy ulicy Korzennej. Po zmianie systemu administrowania miastem, wprowadzonej przez władze pruskie w 1794 r., parter budynku

16 APG, Kolekcja pomorskich planów i map 1634-1945, sygn. 16/1162, Strzelnica św. Jerzego (fasada, rzuty). W 1803 r. przeniesiono tu główny odwach miejski, mieszczący się od 1793 r. w niewielkich budynkach przylegających do znajdującej się obok Katowni. Rok później część budynku zajęła Królewska Szkoła Sztuk Pięknych (Königliche Kunstschule), która zorganizowała w nich mieszkanie dla dyrektora placówki, zob. Josef Nikodemus Pawlowski, Populäre Geschichte Danzig's. Zweiter Theil Beschreibung der hervorragendsten öffentlichen Gebäude Danzigs. Zweiter Abschnitt, Danzig 1883, s. 26; Keyser, Die Baugeschichte der Stadt Danzig..., s. 438.

17 Ibidem, s. 26; Friedrich Karl Gottlieb von Duisburg, Versuch einer historisch-topographischen Beschreibung der freien Stadt Dantzig, Dantzig 1809, s. 186-187.

18 Reprodukcja rysunku odwachu została zamieszczona w pracy Waldemara Krausego, Das Danziger Theather und sein Erbauer Carl Samuel Held, Danzig 1936, s. 88.

${ }_{19}$ Von Duisburg, Versuch einer historisch-topographischen Beschreibung..., s. 187.

20 Eva Börsch-Supan, Zofia Ostrowska-Kębłowska, Karl Friedrich Schinkel. Die Provinzen Ost- und Westpreußen und Großherzogtum Posen, München 2003, s. 701.

${ }_{21}$ GStA PK, I. HA, Rep 76, Kultusministerium, Ve Sekt. 3 Abt. 3, Nr. 1, Bd. 1, s. 25. Zob. także: Bernhard Schmid, Die Denkmalpflege in Westpreussen 1804-1910, Danzig 1910, s. 20. 


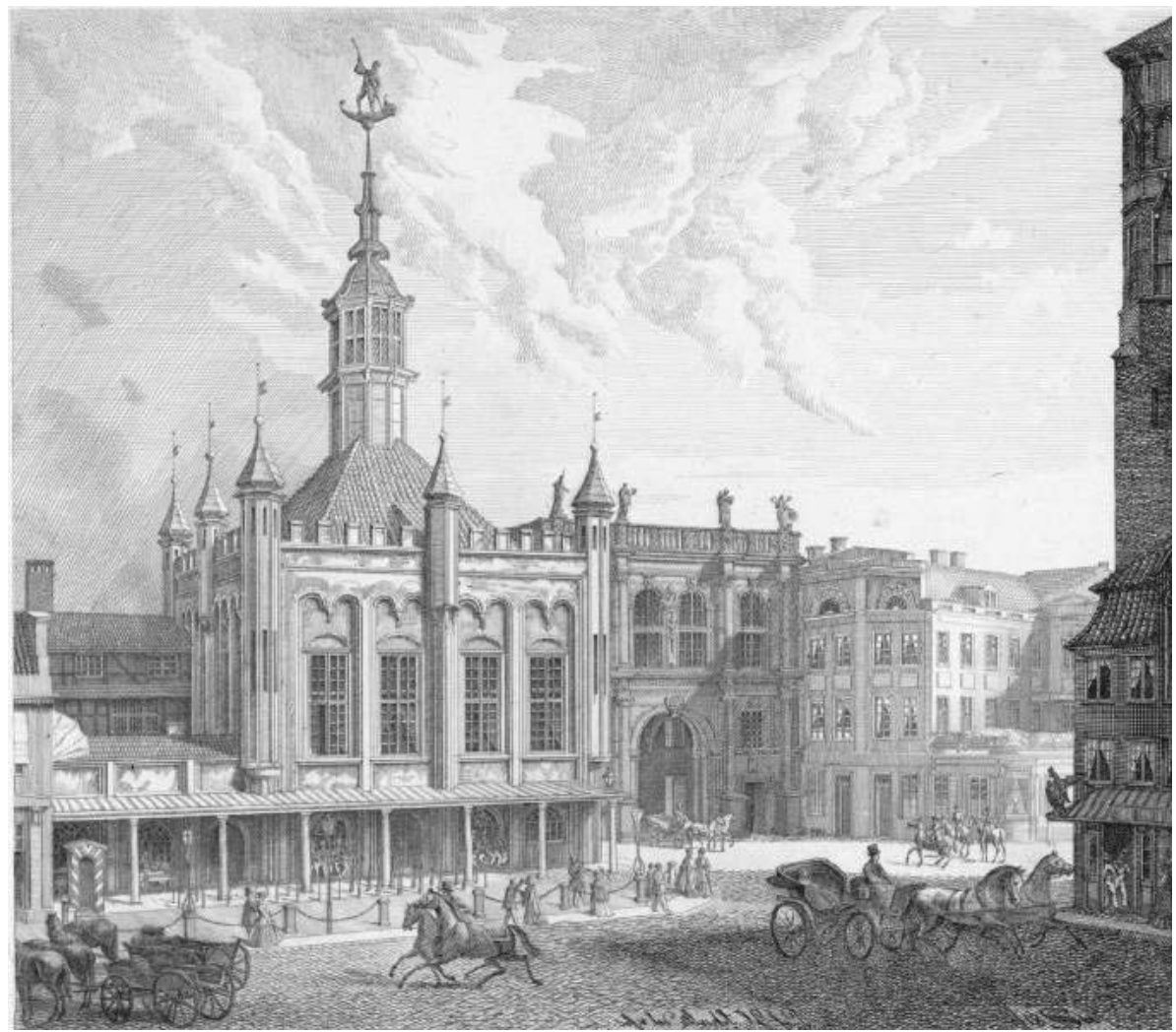

Prze-

kształcenia gdańskich obiektów...

Il. 1. Johann Carl Schultz, widok na Dwór Bractwa św. Jerzego, około 1855, MNG, sygn. MNG/ $\mathrm{SD} / 3663 / \mathrm{G} / 29$

przeznaczono na lokale mieszkalne na wynajem, a na piętrze, w Sali Mieszczańskiej, odbywały się losowania loterii. Wkrótce władze miasta podjęły decyzję o przystosowaniu ratusza do potrzeb Instytutu Położniczego (Hebammen-Institut). Miał on pełnić funkcję szkoły dla położnych i jednocześnie izby porodowej. W odpowiedzi na te oczekiwania Held przygotował w 1798 r. i 1802 r. projekty, które zakładały przeprowadzenie zmian zarówno we wnętrzu budynku, jak i na zewnątrz ${ }^{22}$. Na parterze pomieszczenia miały zostać dostosowane do potrzeb szkółki dla położnych, część z nich przeznaczono na mieszkania. Na pierwszym piętrze rozplanowano salę porodową oraz salę dla hospitalizowanych kobiet. Architekt planował również silne uproszczenie elewacji polegające na redukcji detalu oraz otynkowaniu ceglanych ścian ratusza. Do bardziej widocznych zmian uwzględnionych w projekcie należały: likwidacja sygnaturki, modyfikacja

22 Dwa zachowane warianty przebudowy ratusza na Instytut Położniczy różnią się rozplanowaniem wnętrza, zob. APG, Rejencja w Gdańsku 1713-1911, Plany i mapy, sygn. 18/1536, Ratusz Staromiejski, przebudowa, por. Krause, Das Danziger Theather..., s. 59; Jadwiga Habela, Ratusz Staromiejski w Gdańsku, Gdańsk 1984, s. 38-39. 


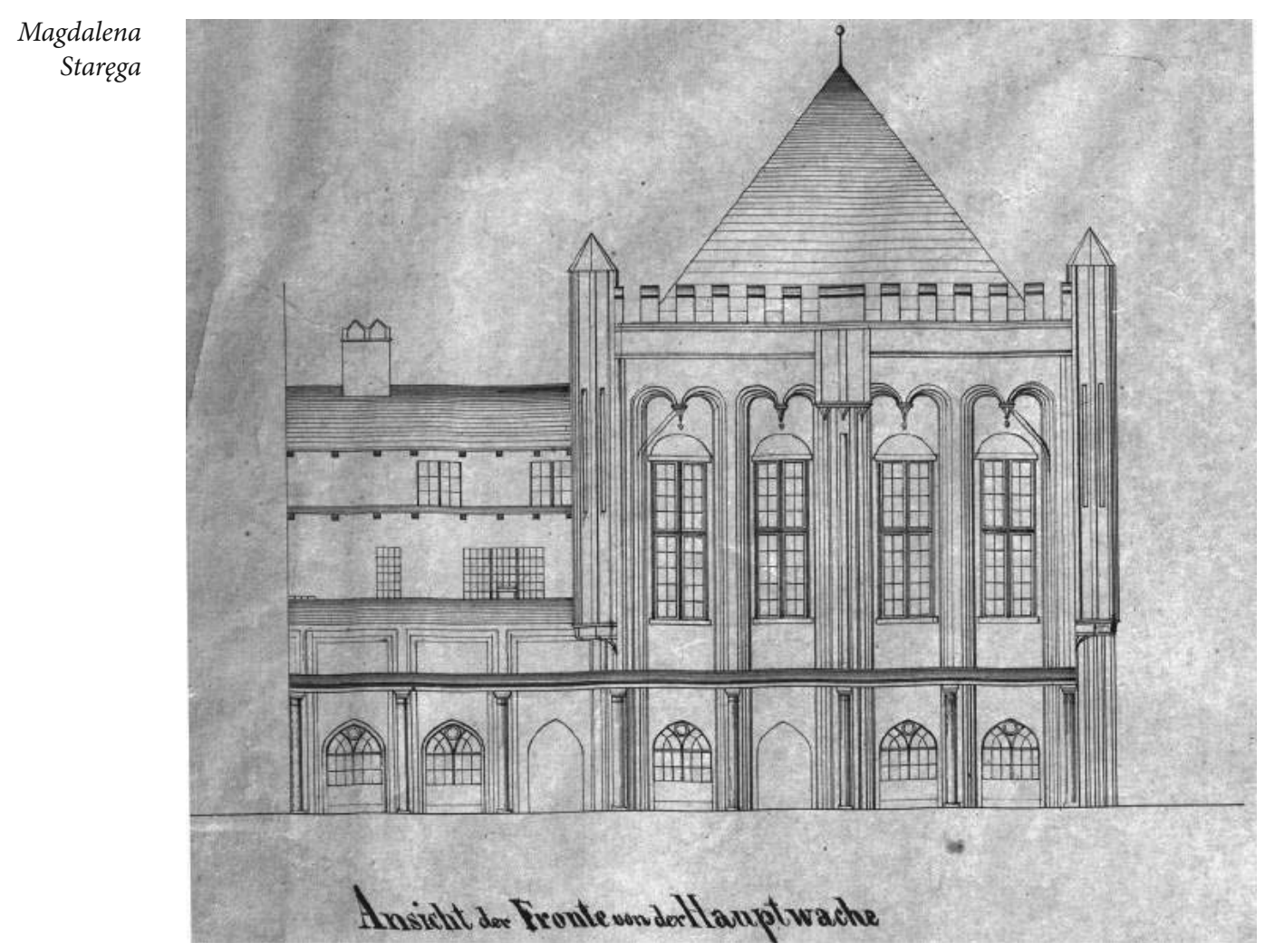

Il. 2. Rysunek inwentaryzacyjny Dworu Bractwa św. Jerzego, 1856, APG, Akta Miasta Gdańska, Kolekcja planów i map 1520-1942, sygn. 16/957

portalu i szczytu na osi budynku oraz przebudowa schodów poprzedzających wejście (il. 3) ${ }^{23}$.

Do realizacji planu nie doszło, a kilka lat później Held sporządził kolejny projekt przebudowy, który ukończono w 1806 r. ${ }^{24}$ Tym razem przestrzeń ratusza postanowiono przeznaczyć na potrzeby sądownicze ${ }^{25}$. Przystosowanie budynku do pełnienia funkcji siedziby Miejskiego i Ziemskiego Sądu dotyczyło głównie jego wnętrza, w którym rozplanowano pomieszczenia sekretariatu, registratury, kancelarii oraz archiwum ${ }^{26}$. Modyfikacje te pociągnęly jednak za sobą konieczność

23 Nie jest do końca jasne, czy różnice w wyglądzie poszczególnych elementów budynku wynikały z rzeczywistego zamiaru ich przekształcenia, czy też Held nie odwzorował dokładnie ówczesnego stanu obiektu. Widoczne na rysunku znacznie powiększone wieżyczki narożne ratusza wynikają prawdopodobnie z nieporadności rysunku, a nie z zamiaru ich przebudowy.

24 APG, Rejencja w Gdańsku 1713-1911, Plany i mapy, sygn. 18/1536, Ratusz Staromiejski, przebudowa. Zob. także: Josef Kaufmann, Studien zur Geschichte der Altstadt Danzig, „Zeitschrift des Westpreußischen Geschichtsvereins” 1913, H. 55, s. 101-103.

25 Wiązało się to z koniecznością zwiększenia liczby pomieszczeń sądu miejskiego, zajmującego kamienicę przy Długim Targu 43, zob. Habela, Ratusz Staromiejski..., s. 38.

26 Von Duisburg, Versuch einer historisch-topographischen Beschreibung..., s. 97. 


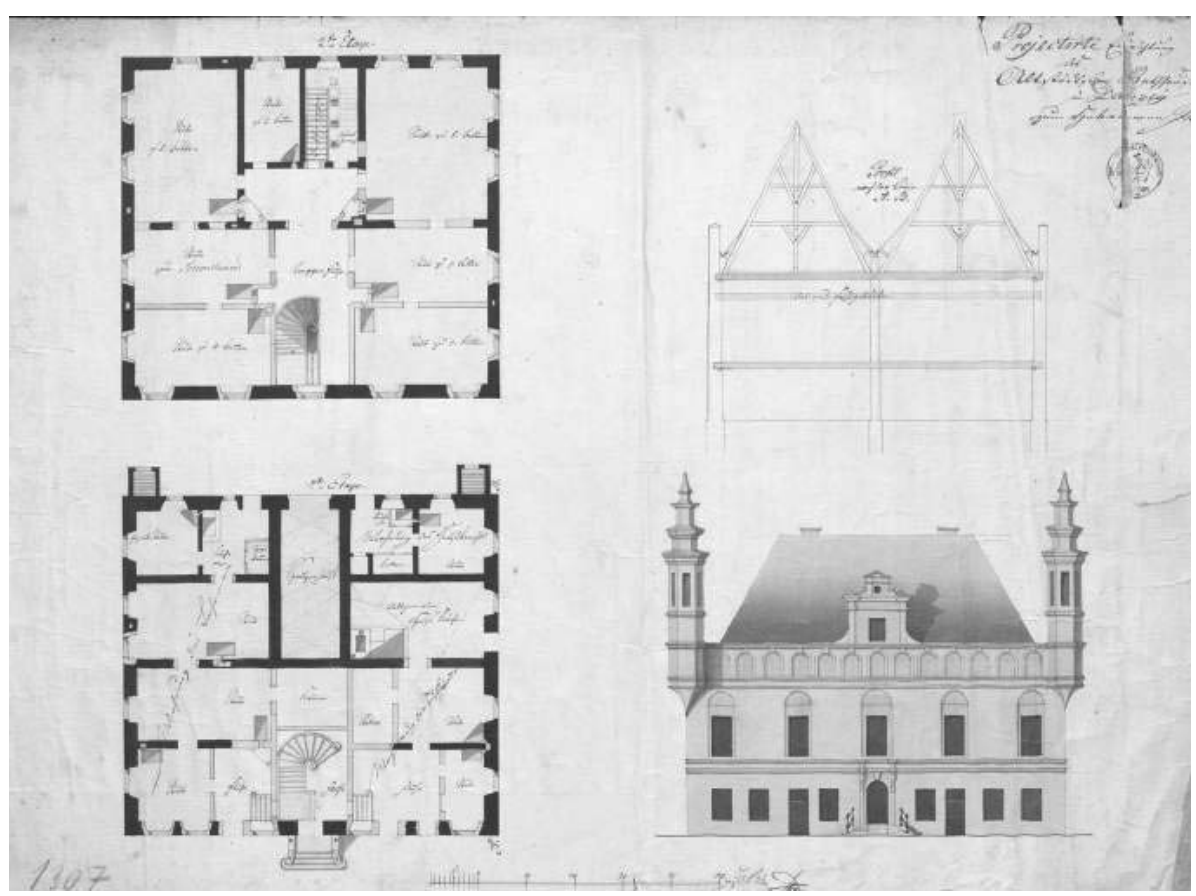

Prze-

kształcenia

gdańskich

obiektów...

Il. 3. Carl Samuel Held, projekt przebudowy Ratusza Staromiejskiego na Instytut Położniczy, 1802, APG, Rejencja w Gdańsku 1713-1911, Plany i mapy, sygn. 18/1536

wprowadzenia zmian w układzie otworów w elewacjach. Aby zatuszować przeprowadzone w ceglanym licu muru przekształcenia, zdecydowano o otynkowaniu budynku i wykonaniu boniowania na poziomie przyziemia (il. 4) ${ }^{27}$.

Architekt miejski był także twórcą koncepcji przebudowy dawnego klasztoru franciszkańskiego znajdującego się na Starym Przedmieściu. W 1805 r. sporządził projekt adaptacji części gotyckiego kompleksu na potrzeby Biblioteki Miejskiej, mieszczącej się tu od końca XVI w. ${ }^{28}$ (il. 5). Impulsem do planowanych zmian były nieodpowiednie warunki do przechowywania i udostępniania stale powiększającego się księgozbioru. Held przewidywał przebudowę zachodniego skrzydła klasztoru. Jak wykazuje porównanie stanu tej części budynku sprzed przebudowy (il. 6) ${ }^{29} \mathrm{z}$ projektem, architekt nie zakładał daleko

27 Wydaje się więc, że pokrycie przyziemia boniowaniem miało miejsce wcześniej, niż sugeruje Jadwiga Habela, która łączy ten zabieg ze wzniesieniem nowego gmachu sądowego za ratuszem około 1860 r., zob. eadem, Ratusz Staromiejski..., s. 40. O przeprowadzonych pracach krytycznie wypowiedział się w swojej publikacji z 1915 r. konserwator zabytków Bernhard Schmid. Stwierdził, że przystosowanie obiektu do nowych funkcji wprowadziło zbyt duże zmiany w układzie wnętrz. W 1910 r. przywrócono wnętrzom ich dawny charakter, zob. Bernard Schmid, Die Denkmalpflege in der Provinz Westpreußen im Jahre 1914, Danzig 1915, s. 9.

28 Von Duisburg, Versuch einer historisch-topographischen Beschreibung..., s. 302.

29 Tę część klasztoru ukazuje rysunek architekta miejskiego Lichta sporządzony w latach siedemdziesiątych XIX w. Należy jednak dopuścić, że w detalach mógł się on różnić od stanu 


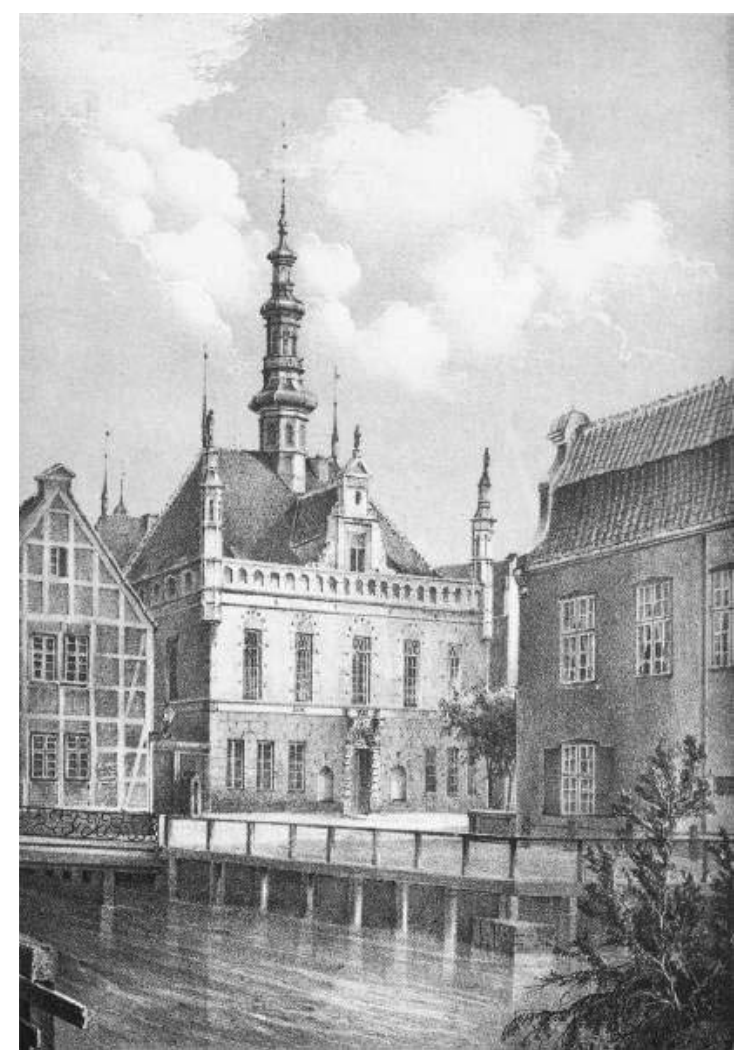

Il. 4. Julius Greth, Ratusz Staromiejski, przed 1860, MNG, sygn. MNG/SD/3986/G idących przekształceń w strukturze obiektu. Planował nadanie bibliotece cech klasycystycznych, kontrastujących z gotycką ścianą szczytową sąsiedniego skrzydła. Jednak przebudowa części zachodniej klasztoru nie wiązała się z zamianą motywów gotyckich na klasycystyczne, bowiem skrzydło to zatraciło swoje cechy stylowe w wyniku rozmaitych prac przeprowadzanych na przestrzeni lat. Co więcej, Held zakładał wykorzystanie dawnych murów oraz zachowanie istniejących $\mathrm{w}$ partii przyziemia krużganków. Do przebudowy nie doszło, inwestycję zatrzymało oblężenie Gdańska przez wojska napoleońskie w $1807 \mathrm{r}^{30}$ Ostatecznie zbiory Biblioteki Miejskiej znalazły się w kościele św. Jakuba, odbudowanym po wybuchu prochu w $1815 \mathrm{r}$. w pobliskiej baszcie, a sam klasztor został poddany gruntownej regotycyzacji dopiero $\mathrm{w}$ drugiej połowie stulecia $^{31}$.

W przypadku gotyckiej Bramy Świętojańskiej, zamykającej ulicę Świętojańską od strony Motławy, efekt klasycystycznej przebudowy widoczny jest do dnia dzisiejszego (il. 7). Wielokrotnie modyfikowana na przestrzeni stuleci budowla największych zmian doczekała się na początku XIX w. Północną jej część zmieniono całkowicie, przekształcając ją w budynek czynszowy, z kolei nad częścią południową, od strony Motławy, wybudowano trójkątny,

z początku stulecia, zob. Julius Albert Gottlieb Licht, Die Wiederherstellung des ehemaligen Franziskaner-Klosters in Danzig, „Notizheft des Westpreussißchen Architekten- und Ingenieur-Verein" 1877, Nr. 1, Bl. 7.

30 Theodor Hirsch, Geschichte des academischen Gymnasiums in Danzig, in ihren Hauptzügen dargestellt, Danzig 1837, s. 58. Zob. także: Jacek Bielak, Budowniczy Miejski Carl Samuel Held i próby modernizacji Gdańska na przełomie XVIII/XIX wieku [w:] Gdańsk i okolice 1793-1914. Miasto - ludzie - wydarzenia w rysunku i grafice, red. Wojciech Bonisławski, Aleksander Baliński, Gdańsk 2014, s. 57-58.

31 Więcej na temat przebudowy klasztoru na potrzeby muzealne zob. Marek Żydowicz, Przebudowa średniowiecznego klasztoru pofranciszkańskiego w Gdańsku jako przyczynek do XIX-wiecznej problematyki konserwatorskiej Prus, „Acta Universitatis Nicolai Copernici. Nauki Humanistyczno-Społeczne. Zabytkoznawstwo i Konserwatorstwo" 1989, t. 13, s. 93-119. 
klasycyzujący szczyt ${ }^{32}$. Aby zatrzeć kontrast powstały po zwieńczeniu ceglanej bramy klasycystycznym szczytem, całość budynku otynkowano. Z kolei gotycką Bramę Mariacką, również częściowo zaadaptowaną na cele mieszkalne, dosięgły zmiany charakterystyczne dla tego czasu - cześć jej przyziemia przystosowano do celów handlowych. W latach czterdziestych XIX w. dokonano zmian $\mathrm{w}$ wyglądzie fasady od strony Motławy, przebijając w niej dodatkowe przeszklenia witryn sklepowych ${ }^{33}$.

W okresie porozbiorowym do rzadkości należały nowe inwestycje o przeznaczeniu administracyjnym. Dlatego też na potrzeby urzędów przebudowano w Gdańsku domy mieszkalne. Rozwiązanie to gwarantowało - poza względami ekonomicznymi - także dobór odpowiedniej dla rangi urzędu lokalizacji. Odkupiono

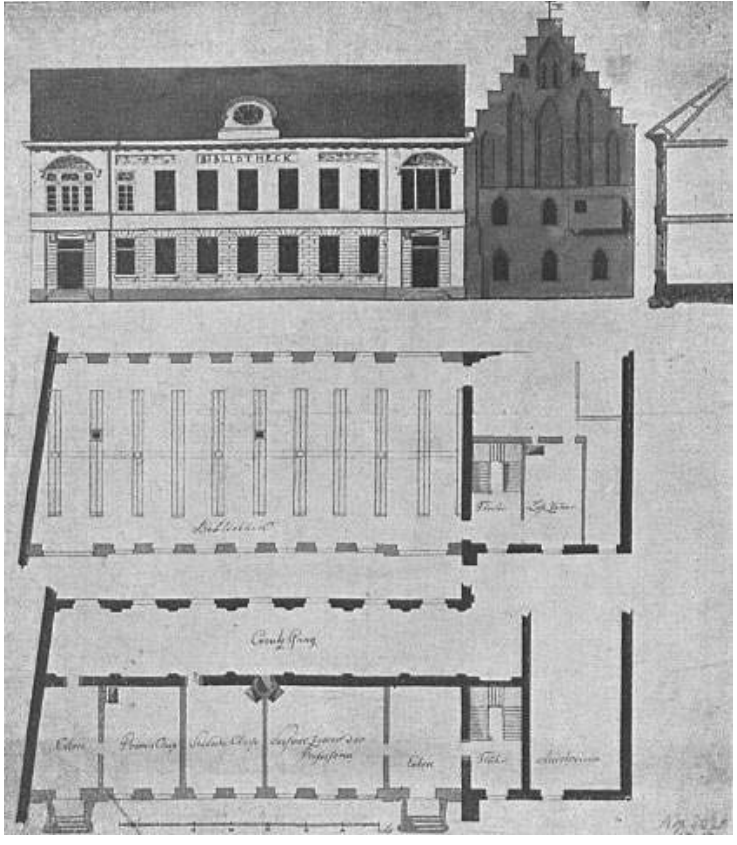

Il. 5. Projekt przebudowy zachodniego skrzydła klasztoru pofranciszkańskiego na potrzeby Biblioteki Miejskiej, repr. za: Waldemar Krause, Das Danziger Theather und sein Erbauer Carl Samuel Held, Danzig 1936 od prywatnych właścicieli kamienice w samym sercu Głównego Miasta przy ulicy Długiej, a następnie dokonano ich przebudowy. W pierwszej kolejności przebudowano kamienice pod numerami 22 i 23, które dostosowano w latach 1831-1834 do pełnienia funkcji siedziby Królewskiej Poczty Pruskiej (Königlische Ober-Postamt in Danzig) ${ }^{34}$. Z kolei w 1835 r., w jej sąsiedztwie, przy ulicy Długiej 25 otwarto nową siedzibę Prezydium Policji w Gdańsku (Königliche Polizeipräsidium in Danzig) ${ }^{35}$. W obu przypadkach dokonano przebudowy wnętrz, przy częściowym zachowaniu dawnych podziałów, a nowa siedziba poczty otrzymała także nowy kostium stylowy. Królewska Szkoła Nawigacji (Königliche Navigationsschule in Danzig) również przystosowała do swoich potrzeb dwa osiemnastowieczne budynki mieszkalne, znajdujące się przy ulicy Karpiej ${ }^{36}$.

32 Grzegorz Sulikowski, Brama Świętojańska, „Gedanopedia”, https://www.gedanopedia. pl/index.php?title=BRAMA_\%C5\%9AWI\%C4\%98TOJA\%C5\%83SKA, [dostęp: 13.02.2018].

33 APG, Państwowy Urząd Policji Budowlanej w Gdańsku, sygn. 15/3147, Frauengasse 27, s. 3.

34 APG, Rejencja w Gdańsku, Plany i mapy 1713-1911, sygn. 18/1609, Gdańsk, Urząd Pocztowy; APG, Rejencja w Gdańsku, Plany i mapy 1713-1911, sygn. 18/1625, Gdańsk, parcele przy ulicy Długiej.

35 APG, Rejencja w Gdańsku, Plany i mapy 1713-1911, sygn. 18/1541, Gdańsk, budynek policji.

36 APG, Rejencja w Gdańsku, Plany i mapy 1713-1911, sygn. 18/1540, Gdańsk, szkoła nawigacyjna. 


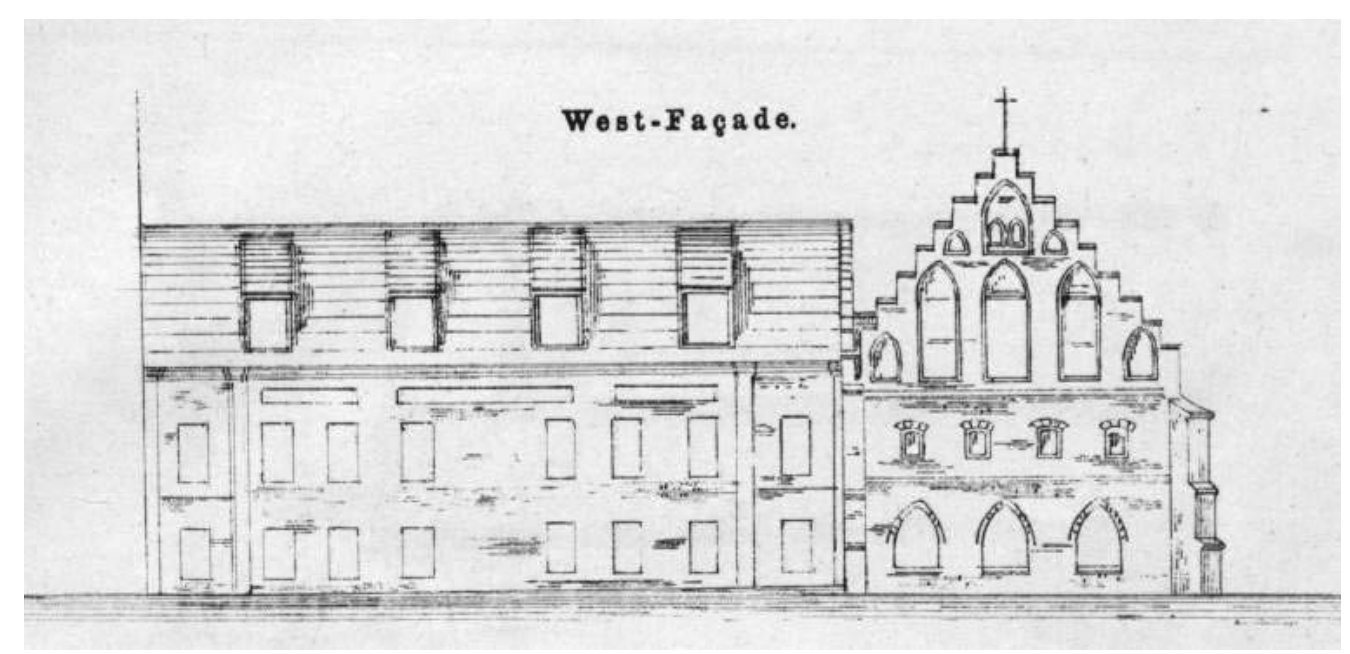

Il. 6. Skrzydło zachodnie klasztoru pofranciszkańskiego przed przebudową w drugiej połowie XIX w., repr. za: Julius Albert Gottlieb Licht, Die Wiederherstellung des ehemaligen Franziskaner-Klosters in Danzig, „Notizheft des Westpreussißchen Architekten- und Ingenieur-Verein” 1877, Nr. 1, Bl. 7

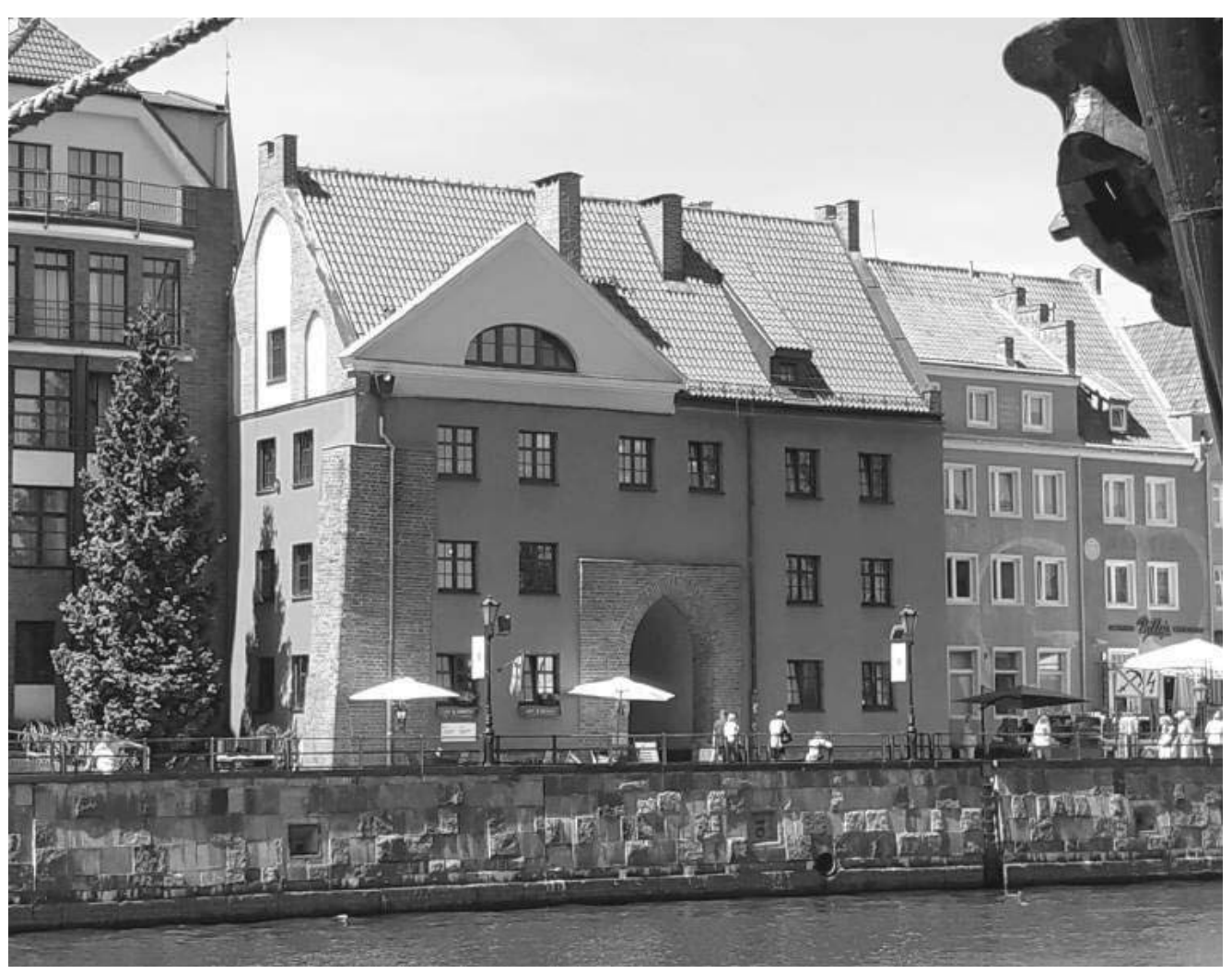

Il. 7. Brama Świętojańska, stan współczesny, fot. Magdalena Staręga 
Zajmowanie i dostosowywanie obiektów mieszkalnych dotyczyło także szeregu innych placówek i miało w owym czasie charakter powszechny.

Jedną z przyczyn przekształcania obiektów zabytkowych były zniszczenia, jakich doznało miasto w czasie oblężenia w latach 1807 i 1813. Zniszczeniom uległy także obiekty sakralne, usytuowane zarówno w obrębie nowożytnych fortyfikacji, jak i poza nimi. Części z nich nigdy nie odbudowano, np. klasztoru reformatów na Chełmie czy Szpitala Wszystkich Bożych Aniołów (Hospital Aller Gottes Engel) przy Wielkiej Alei (ob. al. Zwycięstwa). Te, które doznały stosunkowo niewielkich uszkodzeń, były naprawiane nierzadko przy użyciu bieżących form stylowych. Jednym z czołowych przykładów takiego zabiegu jest barokowy kościół jezuicki na Starych Szkotach. W wyniku bombardowania w 1813 r. stracił obie wieże trójczłonowej fasady ${ }^{37}$. Nie podjęto jednak decyzji o ich odbudowaniu - zamiast wież wprowadzono delikatne spływy łączące obie kondygnacje elewacji. Zgodnie z panującymi wówczas tendencjami zaprojektowano także zwieńczenie w postaci płaskiego, trójkątnego szczytu. Nowym dodatkiem był z pewnością motyw meandra po obu jego stronach. Decyzja o nieodbudowywaniu wież w znaczącym stopniu zmieniła charakter fasady (il. 8). Wymuszona uszkodzeniami zmiana - paradoksalnie - bardziej upodobniła kościół do typowych dla świątyń jezuickich rozwiązań wzorujących się na rzymskim Il Gesu.

W tym samym czasie częściowemu zniszczeniu uległ także kościół Zbawiciela na Zaroślaku. Żołnierze opuszczającej miasto armii napoleońskiej wrzucili do wnętrza budynku granat, niszcząc głównie barokowe wyposażenie obiektu. W Archiwum Państwowym w Gdańsku zachowały się dwa rysunki projektowe wykonane dla kościoła ${ }^{38}$. Wcześniejszy, autorstwa F.G. Fuchsa przewidywał dostawienie do bocznych ścian słupów wspierających nadwątloną konstrukcję (il. 9) ${ }^{39}$. Co warte uwagi, na rysunku uwzględniono klasycystyczny ołtarz, który miał zastąpić zniszczony element wyposażenia. Dwa rysunki podobnego ołtarza zachowały się również w kolekcji rycin Muzeum Narodowego w Gdańsku (il. 10 ${ }^{40}$. Ich zbieżność formalna pozwala przypuszczać, że ich autorem również był Fuchs. Niestety, brakuje źródeł odnoszących się do historii obiektu po 1814 r., pozwalających na ustalenie szczegółów odbudowy i rekonstrukcji wyposażenia.

37 Wilhelm Ferdinand Zernecke, Cały Gdańsk za dwadzieścia srebrnych groszy. Najnowszy przewodnik po Gdańsku i jego okolicy. Alfabetycznie ułożony opis wszystkiego, co w Gdańsku i okolicy jest godne uwagi lub w jakikolwiek sposób interesujące, tłum. Roman Kowald i Aleksander Masłowski, Gdańsk 2010 (oryg. Danzig 1843), s. 95. Koszty ukończonej w 1817 r. odbudowy wynoszące 6 tys. talarów pokryto ze środków prywatnych, zob. „Danziger Dampfboot”, 11.07.1839, s. 661.

38 APG, Akta Miasta Gdańska, 1520-1942, sygn. 16/978, Petershagen pod Gdańskiem, kościół.

39 Zamysł ten zrealizowano w drugiej połowie XIX w., dostawiając do bocznych ścian kościoła neogotyckie przypory.

40 Muzeum Narodowe w Gdańsku [dalej: MNG], Zbiory Pracowni Rysunku, sygn. MNG/ SD/1000/R, MNG/SD/1001/R. 


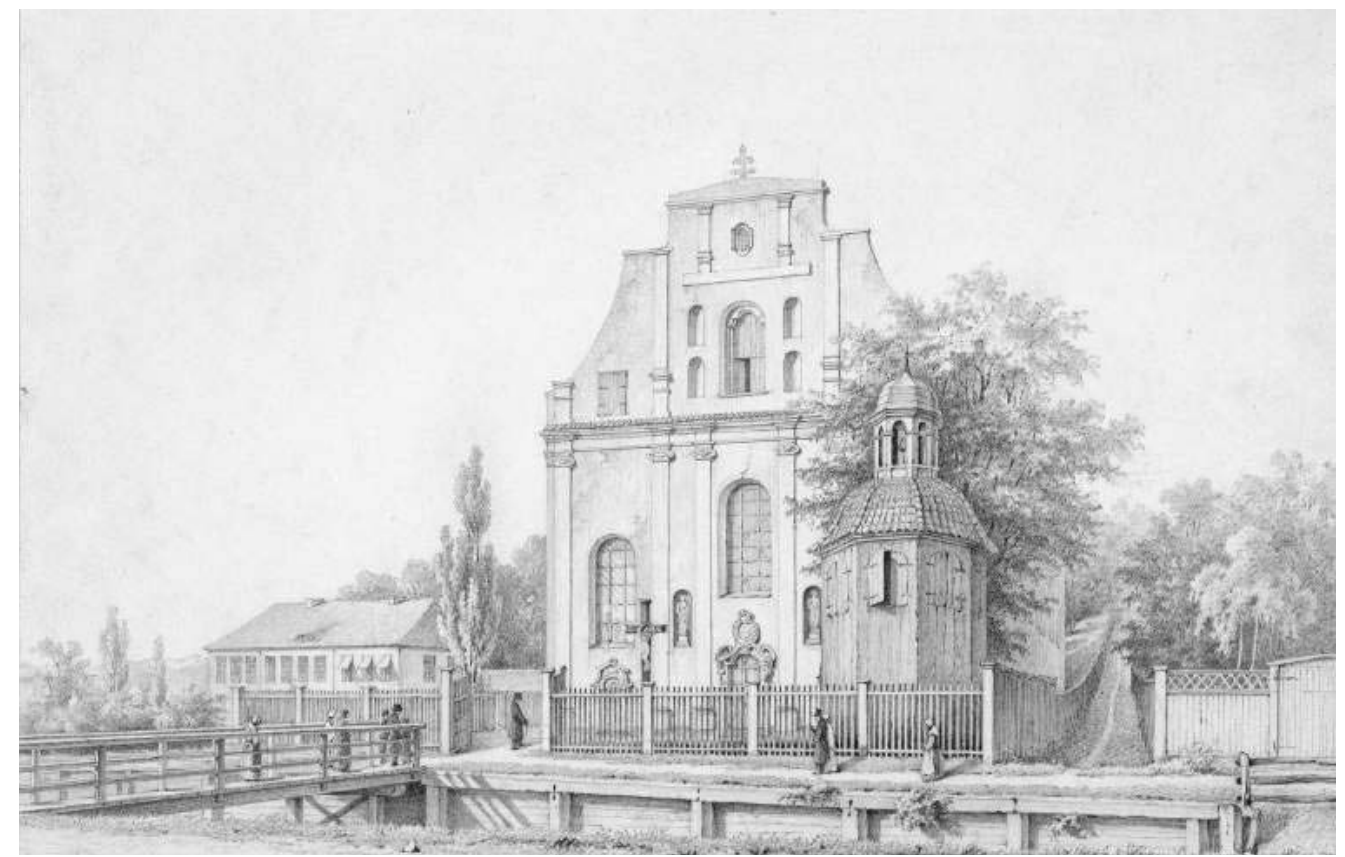

Il. 8. Kościół jezuicki na Starych Szkotach po odbudowie, MNG, sygn. MNG/SD/445/R

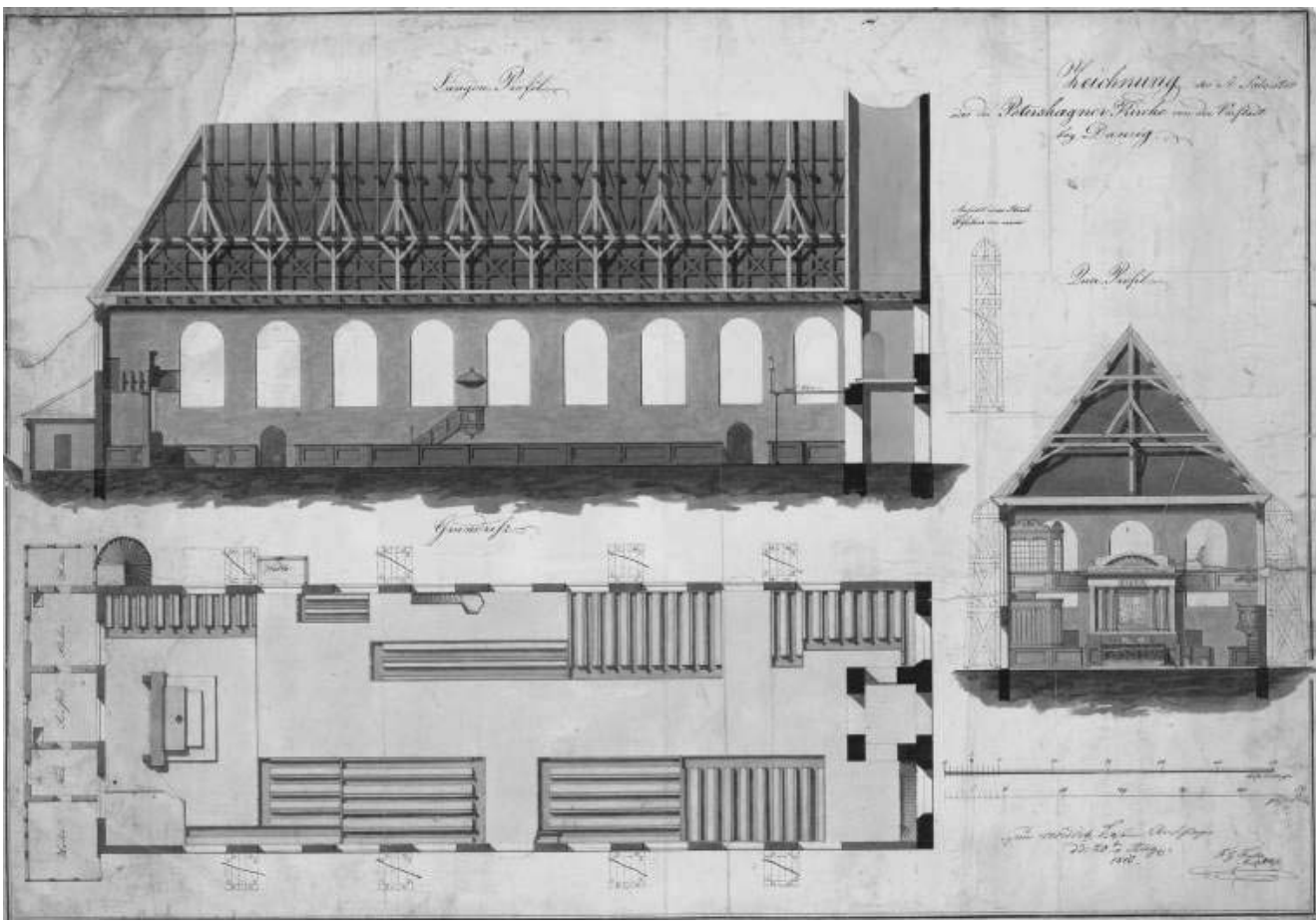

Il. 9. F.G. Fuchs, kościół Zbawiciela na Zaroślaku, projekt wzmocnienia konstrukcji kościoła, 1816, APG, Akta Miasta Gdańska, Kolekcja planów i map 1520-1942, sygn. 300MP/978 

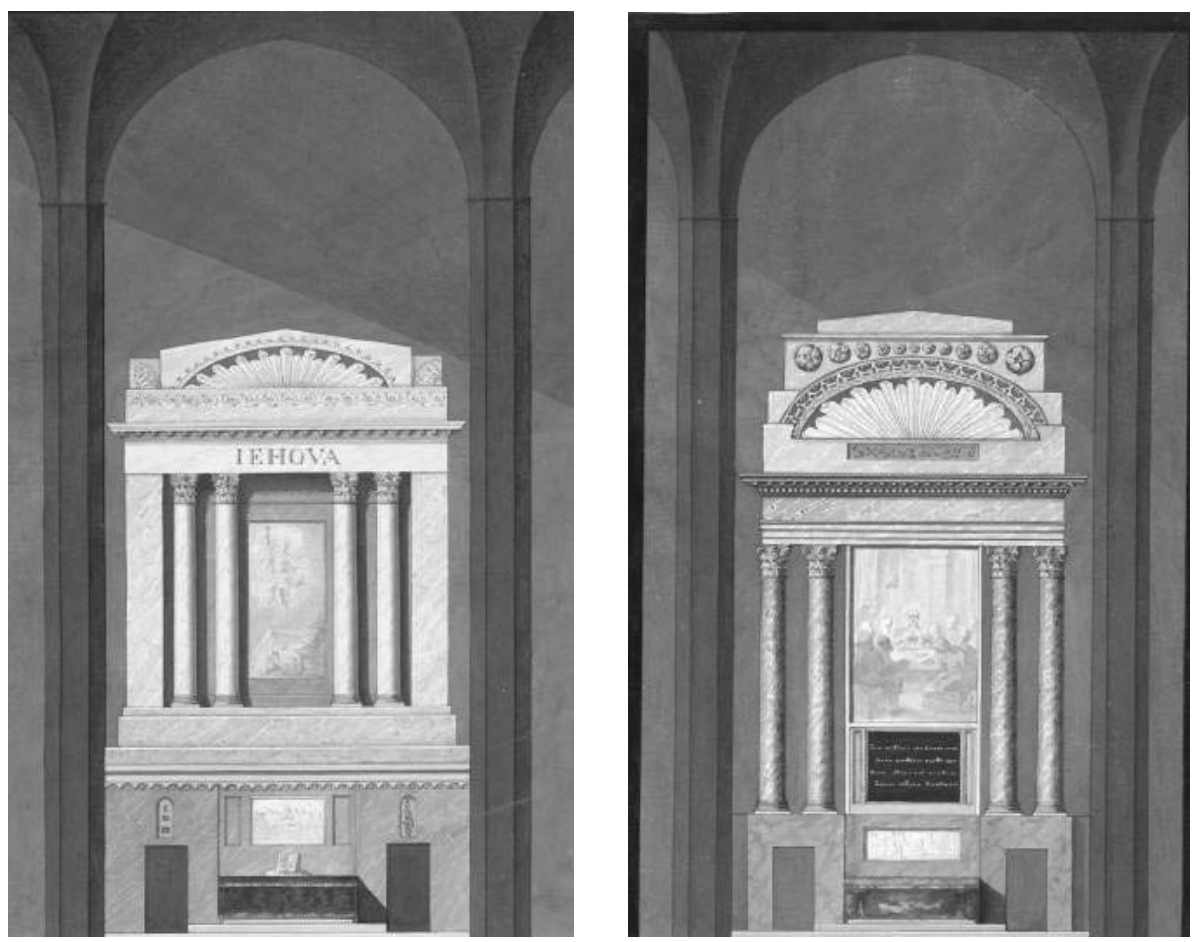

Prze-

kształcenia

gdańskich

obiektów..

Il. 10. Domniemane projekty nowego ołtarza dla kościoła Zbawiciela na Zaroślaku, MNG, sygn. MNG/SD/1000/R, MNG/SD/1001/R

Długotrwały proces przywracania kościoła do stanu używalności zakończono dopiero w $1826 \mathrm{r}^{41} \mathrm{~W} 1815 \mathrm{r}$. w wyniku wybuchu leżącej niedaleko baszty prochowej częściowo zniszczony został zespół kościelno-szpitalny św. Jakuba na Starym Mieście ${ }^{42}$. Najbardziej ucierpiały więźba dachowa oraz hełm ukończonej w 1639 r. wieży kościoła. Naprawa okazała się na tyle kosztowna, że ówczesny właściciel budynku, fundacja szpitala św. Jakuba, postanowił oddać go w dzierżawę. Nowymi użytkownikami zostały Królewska Szkoła Nawigacji, która ulokowała się w prezbiterium, oraz Biblioteka Miejska (Danziger Stadtbibliothek), która zajęła nawę ${ }^{43}$. Zmiany wprowadzone we wnętrzu były duże, jednak nie istnieją

41 August Brandstäter, Chronologische Übersicht der Geschichte Danzigs, Danzig 1879, s. 71. Stan budynku po odbudowie uwieczniony został na rysunku inwentaryzacyjnym z $1836 \mathrm{r}$., zob. APG, Akta Miasta Gdańska. Kolekcja planów i map 1520-1942, sygn. 300MP/978, Petershagen pod Gdańskiem - kościół.

${ }^{42}$ Adam Szarszewski, Szpital i kościół św. Jakuba w Gdańsku, Zarys historyczny, Toruń 2000, s. 103.

43 Królewska Szkoła Nawigacji zajmowała kościół od 1817 r. do czasu przenosin do nowo otwartej siedziby przy ulicy Karpiej. Z kolei Biblioteka Miejska funkcjonowała w budynku kościoła od 1821 do 1905 r., zob. Maria Pelczar, Kościół św. Jakuba - Biblioteką Miejska [w:] Szpital i kościót św. Jakuba. 600 lat fundacji gildii szyprów w Gdańsku, red. Adam Sroka, Toruń 2009, s. $243-244$ 
Magdalena Starega

źródła ikonograficzne ukazujące ich skalę $e^{44}$. Uwieczniono za to sylwetę kościoła wraz $\mathrm{z}$ wieżą, której nowa forma stała się symbolem zmiany funkcji budowli z sakralnej na świecką (il. 11). Dla szkoły nawigacyjnej była ona elementem znaczącym - dostosowano ją bowiem do funkcji punktu obserwacyjnego i miejsca nauki obsługi sprzętu nawigacyjnego ${ }^{45}$. Nie odbudowano hełmu, a zamiast niego na szczycie wieży wprowadzono płaski taras ogrodzony prostą, klasycystyczną balustradą. Zrezygnowano też z niewielkiej sygnaturki, zastępując ją kominem obsługującym system ogrzewania sal lekcyjnych w szkole.

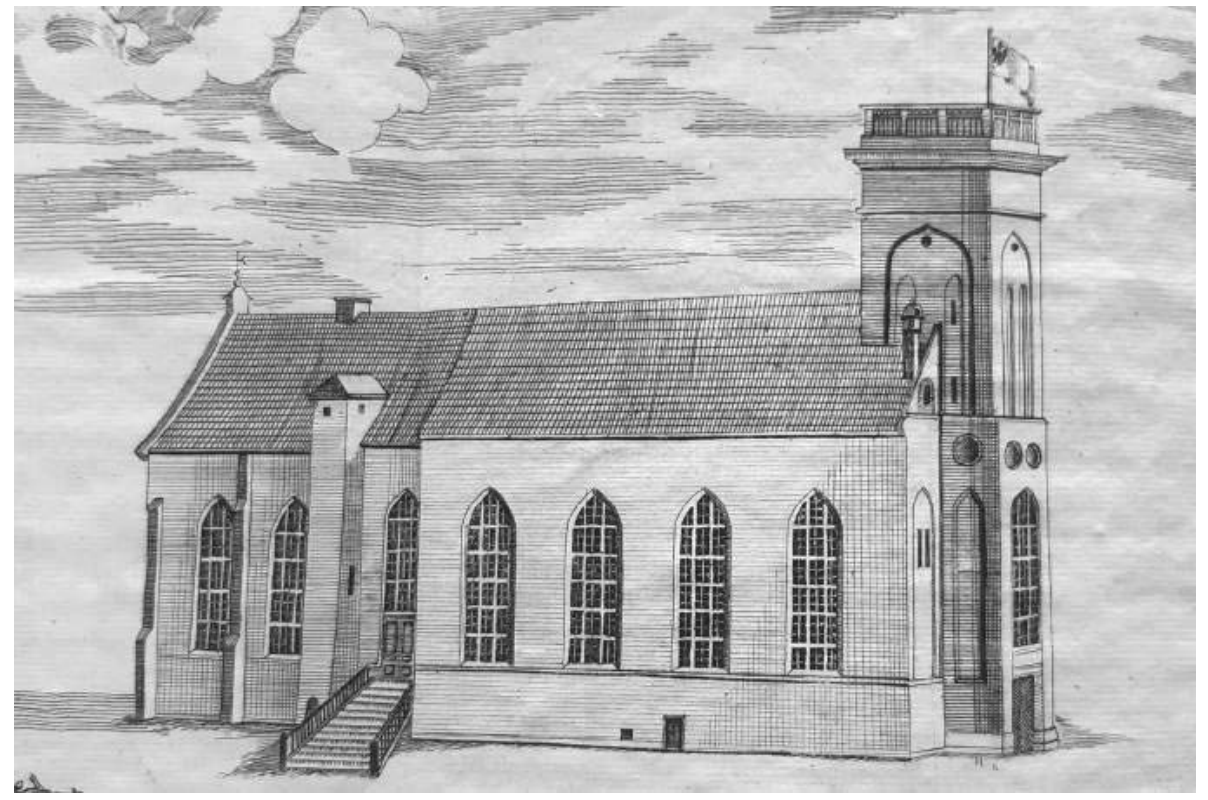

Il. 11. Kościół św. Jakuba jako siedziba Królewskiej Szkoły Nawigacji, repr. za: Kurze Nachricht von der in Danzig errichteten Königlichen nautischen Lehranstalt: nebst einer Beschreibung von Massey's Patent Logg und Patent Loth, Danzig 1818

W wyniku wybuchu baszty prochowej ucierpiał także leżący w jej pobliżu piętnastowieczny kościół św. Bartłomieja. Eksplozja uszkodziła strop oraz wyposażenie budowli. Podczas odbudowy w 1815 r. zastąpiono stary drewniany strop belkowy sklepieniem zwierciadlanym ${ }^{46}$.

44 Opis przeprowadzonych prac adaptacyjnych zawarł w swoim artykule Aleksander Piwek, Architektura i kościół św. Jakuba w Gdańsku [w:] Szpital i kościól św. Jakuba..., s. 152-158.

45 Ibidem, s. 155; Adam Szarszewski, Szpital i kościół św. Jakuba w Gdańsku, Zarys historyczny, Toruń 2000, s. 105.

${ }^{46}$ Dehio-Handbuch der Kunstdenkmaler West und Ostpreussen: die ehemaligen Provinzen West und Ostpreussen (Deutschordensland Preussen) mit Bütower und Lauenburger Land, oprac. Michael Antoni, München-Berlin 1993, s. 101. Z kolei w 1821 r. usunięto znajdujące się na ścianie zachodniej kościoła barokowe portale prowadzące na znajdujący się przy kościele cmentarz, zob. ibidem. 
Ograniczone środki na prace renowacyjne sprawiały, że koncentrowano się głównie na najpilniejszych naprawach i przebudowach. O ile stan techniczny danego obiektu nie był przeszkodą w jego dalszym użytkowaniu, nie decydowano się na modernizację lub przywrócenie utraconych części. Tak było chociażby w przypadku kościołów św. Ducha oraz św. Jana, które straciły sygnaturki podczas oblężenia w 1807 r., ale ich odbudowy się nie podjęto. $Z$ kolei około 1820 r. w kościele św. św. Piotra i Pawła na Starym Przedmieściu usunięto iglicę z dachu nad prezbiterium, najprawdopodobniej ze względu na jej stan techniczny. Jej również nie odbudowano ${ }^{47}$.

Lata dwudzieste i trzydzieste XIX stulecia przyniosły w Gdańsku znaczną liczbę przekształceń zabytkowych budowli, wynikających głównie z ich modernizacji, niekiedy wymuszonej pogarszającym się stanem technicznym. W wypadku tego typu zabiegów również dochodziło do połączenia różnych form stylowych. Czołowym tego przykładem jest powstała w 1568 r. Brama Zielona, stanowiąca zamknięcie biegnącego przez ulice Długą i Długi Targ Traktu Królewskiego. Przeprowadzone tu prace budowlane wiązały się nie tylko ze złym stanem technicznym budynku, ale także ze zmianą jego użytkownika - od 1746 r. do 1830 r. część pomieszczeń bramy dzierżawiło Gdańskie Towarzystwo Przyrodnicze (Naturforschende Gesellschaft in Danzig) ${ }^{48}$. Po wygaśnięciu dzierżawy w $1831 \mathrm{r}$. władze miejskie przystąpiły do przekształcania reprezentacyjnej budowli w miejsce przeznaczone do organizacji koncertów, balów czy wystaw sztuki ${ }^{49}$. Nadwątlona struktura szczytów wpłynęła na decyzję o ich rozbiórce, rozebrano też wysoki dwuspadowy dach ${ }^{50}$. Wprowadzono trzecią, zasłoniętą wysoką attyką kondygnację, którą przykryto płaskim dachem (il. 12). Zachowano dawne podziały pilastrami jońskimi, a pomiędzy nimi wprowadzono prostokątne płyciny z płaskorzeźbami, rezygnując przy tym z okien. Na wysokości trzeciej kondygnacji występowały one jedynie w elewacjach szczytowych części głównej oraz w skrzydłach. Całość zwieńczona została balustradą z ustawionych na przemian figur i słupków, będących elementami kamieniarki rozebranych szczytó $w^{51}$. Wykorzystanie przez autora przebudowy, architekta miejskiego Helda pierwotnych fragmentów budynku w nowej aranżacji stylowej było w tym czasie zjawiskiem odosobnionym. Nie należy jednak wiązać tych działań ze świadomością ich architektonicznej

47 Wolfgang Günter Deurer, Danzig. Die Dokumentation 52 historischer Kirchen, Wesel 1996, s. 35; Keyser, Die Baugeschichte der Stad Danzig..., s. 443; Arkadiusz Staniszewski, Fara gdańskiego przedmieścia. Przegląd ikonografii i spojrzenie na architektoniczne dzieje kościoła św.św. Piotra i Pawła w Gdańsku, Gdańsk 2015, s. 30-31. Zob. także: Dehio-Handbuch..., s. 100; Instytut Herdera w Marburgu [dalej: IH], DSHI 100, Drost 17, Johannis Kirche, s. 19.

48 Neuer Führer durch Danzig und Umgegend, Danzig 1889, s. 19.

49 Matthias Gotthilf Löschin, Danzig und seine Umgebungen, Danzig 1836, s. 42. Zob. także: „Danziger Dampfboot”, 14.11.1840, s. 1107-1108; „Danziger Dampfboot”, 8.02.1834, s. 69-70.

50 Löschin, Danzig und seine Umgebungen..., s. 40. Najprawdopodobniej rozebrano dwie górne z trzech kondygnacji szczytów.

51 Pawlowski, Populäre Geschichte..., s. 24. 


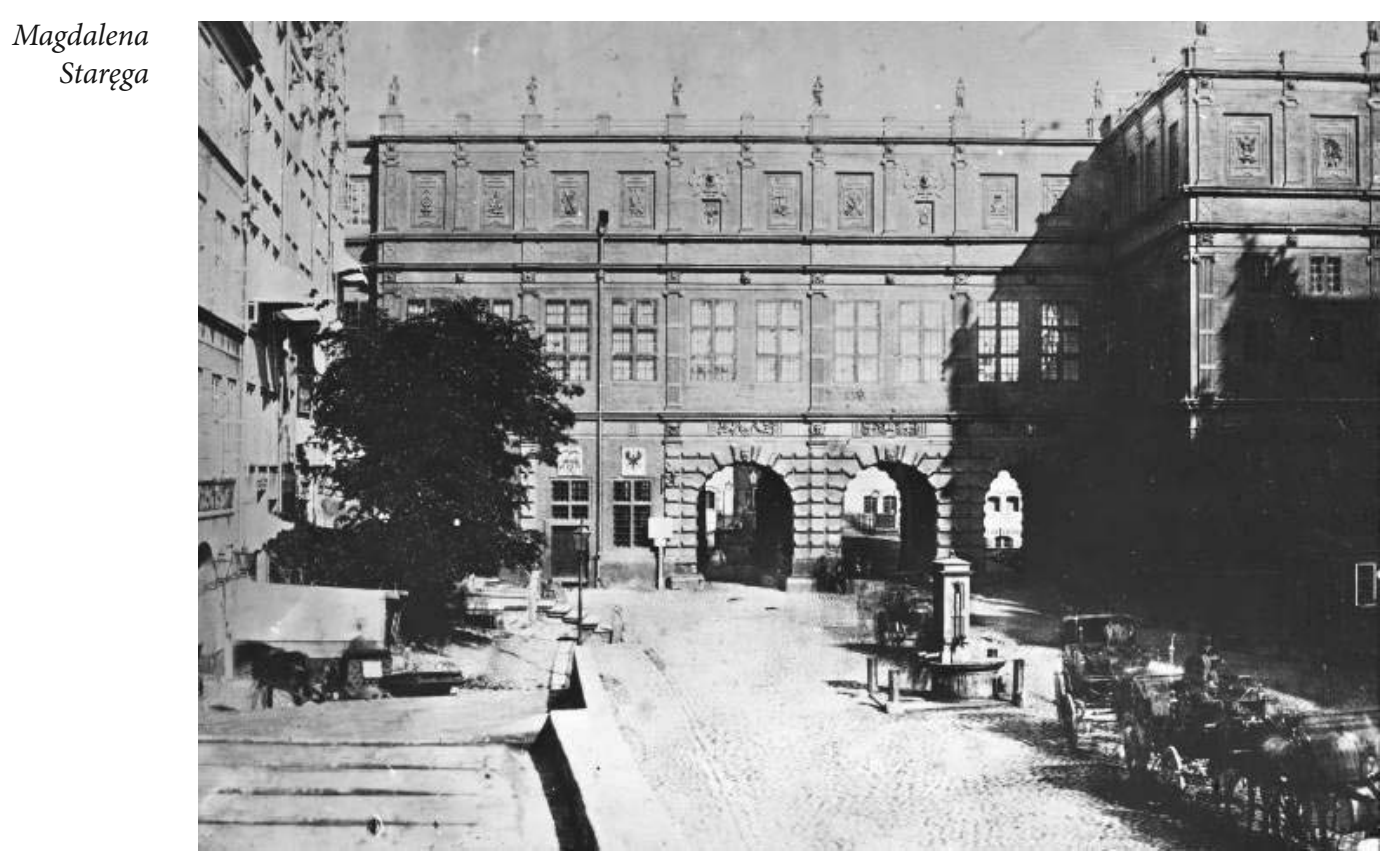

Il. 12. Brama Zielona po przebudowie szczytu, IH, Bildarchiv, sygn. 148976

i historycznej wartości ${ }^{52}$. W wypadku renesansowej Bramy Zielonej, której nie przypisywano wówczas szczególnej wartości architektonicznej czy historycznej, była to raczej próba zatarcia różnic formalnych pomiędzy starą a nową częścią ${ }^{53}$. Jednak niezależnie od intencji architekta pozbawienie bramy charakterystycznych szczytów diametralnie zmieniło wygląd obiektu.

Likwidacja szczytów dotknęła także znajdującą się przy Placu Wałowym na Starym Przedmieściu Małą Zbrojownię. Zbudowany w 1645 r. magazyn wojskowy, w XIX w. nadal użytkowany był jako skład militariów. W 1833 r. likwidacji uległy poprzeczne części dachów, szczyty na ich zakończeniach oraz bramy od strony placu, na którym wykonywano musztrę $e^{54}$. Pozostałe wejścia także zostały przebudowane. W efekcie przeprowadzonych prac poważnie zniekształcono pierwotną bryłę budynku (il. 13). Nie jest znany powód tych

${ }^{52}$ Renesans w wydaniu północnym zyskał na znaczeniu dopiero po zjednoczeniu Niemiec, zob. Rafał Makała, „Neorenesans pótnocny” jako niemiecki styl narodowy na przełomie XIX i XX w. [w:] Recepcja renesansu w XIX i XX wieku. Materiały Sesji Stowarzyszenia Historyków Sztuki, Łódź, listopad 2002, red. Małgorzata Wróblewska-Markiewicz, Łódź 2003, s. 308.

53 Historyczne dziedzictwo Bramy Zielonej, mającej w przeszłości służyć jako okazjonalna siedziba polskich władców, z pewnością nie wpływało na wzrost jej znaczenia u Prusaków. Z kolei jej destrukcja może być odczytywana jako objaw lekceważenia czasów i wydarzeń, jakich była świadkiem. Za cenne uwagi dotyczące przebudowy obiektu serdecznie dziękuję Pani prof. dr hab. Małgorzacie Omilanowskiej.

${ }^{54}$ Jerzy Stankiewicz, Bohdan Szermer, Gdańsk. Rozwój urbanistyczny i architektoniczny oraz powstanie zespołu Gdańsk-Sopot-Gdynia, Warszawa 1959, s. 202. 


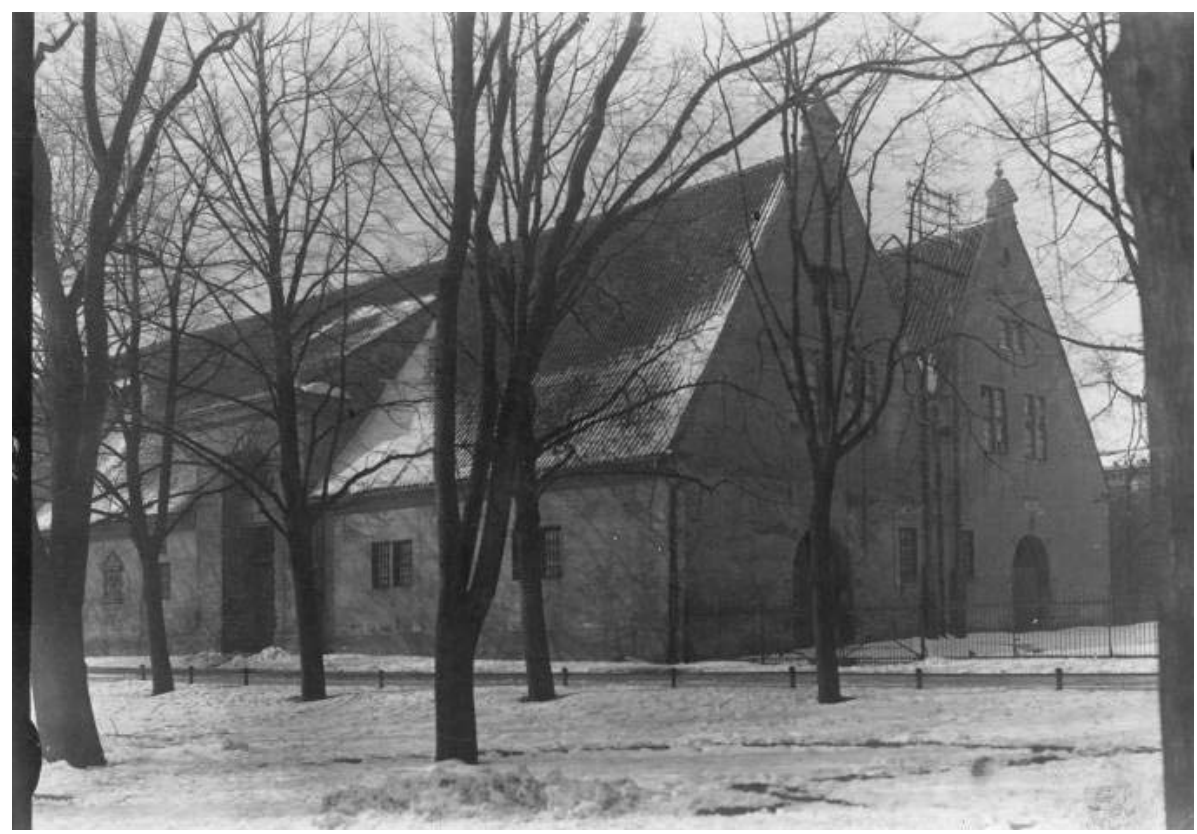

Prze-

kształcenia gdańskich obiektów...

Il. 13. Mała Zbrojownia, stan po przebudowie, PAN BG, sygn. AL IV/6/25

zabiegów, być może na decyzję o wprowadzeniu zmian ponownie miał wpływ stan techniczny obiektu.

Na początku trzeciej dekady XIX w. w architekturze gdańskiej pojawił się pierwszy przykład historyzmu w postaci neogotyckiego kościoła ewangelickiego w Oruni ${ }^{55}$. Powstanie tej budowli zapoczątkowało powolny proces adaptacji form neogotyckich na gruncie gdańskim, co wkrótce przełożyło się także na dobór środków formalnych stosowanych przy przeprowadzanych przebudowach. Rosnąca świadomość wartości obiektów zabytkowych, za jakie wówczas uważano budowle gotyckie, decydowała o tym, że w podejmowanych w następnych latach rozbudowach i modernizacjach decydowano się na zachowanie jedności stylowej. W 1830 r. nowo mianowany dyrektor berlińskiej Wyższej Deputacji Budowlanej Karl Friedrich Schinkel opracował projekt rozbudowy znajdującego się przy Długim Targu Dworu Artusa, w którym mieściła się wówczas giełda ${ }^{56}$. Zachowane rysunki przedstawiają rzut, przekroje, fasadę oraz detale

55 Więcej o budynku kościoła zob. Börsch-Supan, Ostrowska-Kębłowska, Karl Friedrich Schinkel..., s. 287-289.

56 Projekt Schinkla szczegółowo opisał w swoim artykule Carl von Lorck. Wysunął on hipotezę, że rysunki wyszły spod ręki współpracownika Schinkla, Ludwiga Persiusa, ale powstały na podstawie szkiców Schinkla i były przez niego sygnowane, zob. Carl von Lorck, Schinkels Anbau für den Danziger Artushof, „Ostdeutsche Monatshefte” 1936, Jg. 16, H. 11, s. 647-653; zob. także: Börsch-Supan, Ostrowska-Kębłowska, Karl Friedrich Schinkel..., s. 79-84; Arszyński, Działalność Karola Fryderyka Schinkla, s. 94-96. Projekt Schinkla poprzedziły rysunki inwentaryzacyjne, 
Magdalena Starega

nowego aneksu (il. 14). Planowana zmiana dotyczyła tylnej części budynku, znajdującej się przy ulicy Chlebnickiej. Różnego rodzaju przybudówki, jakie powstały po tej stronie obiektu w ciągu wielu lat, miały zostać zlikwidowane.

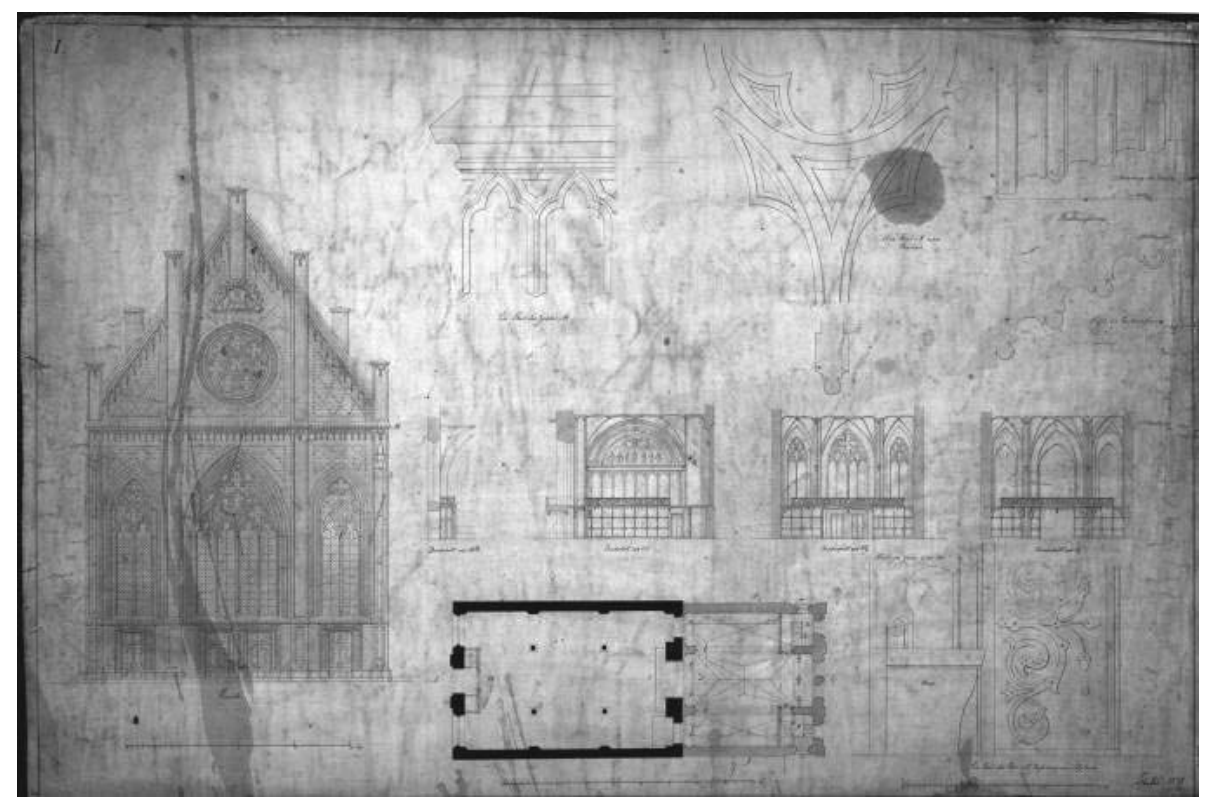

Il. 14. Karl Friedrich Schinkel, projekt aneksu do Dworu Artusa, 1830, Kupferstichkabinett, Staatliche Museen zu Berlin, sygn. SM D.3

Na ich miejscu planowano wznieść jednokondygnacyjny neogotycki aneks, o podobnej szerokości co Dwór Artusa. Jego trójosiowa, symetryczna elewacja powtarzać miała układ gotyckiej tylnej elewacji budynku. Dominującym elementem projektu były trzy wysokie, ostrołukowe okna z bogatą dekoracją maswerkową. Do wnętrza prowadziły cztery jednakowe wejścia w postaci drewnianych drzwi z okuciami. W partii szczytu Schinkel planował zaś wprowadzić dużych rozmiarów rozetę oraz herb Gdańska. Lizeny flankujące elewację i oddzielające od siebie okna przechodziły w partii szczytu w wysokie sterczyny zakończone niskim daszkiem czterospadowym. Mnogość dekoracji oraz proste podziały dawały niezwykle reprezentacyjny efekt. Wnętrze zaprojektowanej sali odzwierciedlało układ elewacji: środkowa część była szersza, przekryta sklepieniem gwiaździstym; w częściach bocznych rozplanowano empory oraz sklepienia krzyżowe. Wejścia boczne prowadziły bezpośrednio na klatki schodowe, którymi można było się dostać na empory. Mimo iż projekt zakładał dużą ingerencję w kształt wysokiej klasy zabytku, jakim jest

wykonane przez Helda w 1823 i 1829 r., zob. ibidem, s. 80; APG, Akta Miasta Gdańska, Kolekcja planów i map, 1520-1942, sygn. 16/953, Gdańsk, Dwór Artusa; Staatliche Museen zu Berlin, Kupferstichkabinett, Danzig (Gdańsk), sygn. SM OBD 41, Artushof (Junkerhof). Grundriss, Profil und Vorderansicht, Held 1826. 
Dwór Artusa, jego twórca przewidywał także pewne odwołania do lokalnego budownictwa, np. w formie sklepień gwiaździstych czy wciągnięcia do wnętrza budowli przypór ${ }^{57}$.

Do realizacji projektu nie doszło. Gdański zabytek doczekał się jednak innej przebudowy, która miała miejsce dekadę później. Zmiany ponownie dotyczyły tylnej elewacji obiektu. Tym razem miały na celu jej odsłonięcie i przywrócenie dawnego wyglądu. Efekty tych prac stanowią jeden z najważniejszych przykładów regotycyzacji na lokalnej scenie architektonicznej. Odwiedzający w $1854 \mathrm{r}$. Gdańsk znawca architektury Wilhelm Lübke jako twórcę planów przebudowy podał Schinkla ${ }^{58}$. Nie zachowały się jednak żadne projekty bądź inne przekazy źródłowe wskazujące jednoznacznie na autora koncepcji59. Tymczasem ranga zabytku, jakość projektu a także zaangażowanie architekta w prace w $1830 \mathrm{r}$. mogą przemawiać za zasadnością tej tezy ${ }^{60}$.

W 1839 r. przystąpiono do porządkowania działki przed tylną elewacją Dworu Artusa, usuwając nawarstwione przez lata aneksy. W następnej kolejności przeprowadzono prace elewacyjne. Zachowana ikonografia pozwala na szczegółowe porównanie stanu przed przebudową i po ${ }^{61}$. Cześć zabiegów polegała na odtworzeniu dawnego kształtu elewacji - na nowo przebito częściowo zamurowane okna, przywracając zaburzoną symetrię, obłożono ścianę licówką i zrekonstruowano ceglane detale. Prace objęly również wprowadzanie nowych, obcych względem pierwotnej formy budynku, rozwiązań (il. 15). Najbardziej charakterystycznym elementem przebudowy były szczyty, które zostały uwydatnione

57 Arszyński, Działalność Karola Fryderyka Schinkla..., s. 95; Andrzej Grzybkowski, Schinkla projekt rozbudowy Dworu Artusa w Gdańsku [w:] Artifex doctus. Studia ofiarowane profesorowi Jerzemu Gadomskiemu w siedemdziesiąta rocznicę urodzin, t. 1, red. Wojciech Bałus, Wojciech Walanus, Marek Walczak, Kraków 2007, s. 316-317; Jacek Friedrich, Walka obrazów. Przedstawienia wobec idei w Wolnym Mieście Gdańsku, Gdańsk 2018, s. 30.

58 Wilhelm Lübke, Architektonische Mittheilungen, gesammelt auf der Bereisung der Preuß. Ostbahn im Juli 1854, „Zeitschrift für Bauwesen” 1855, Jg. 5, H. 1, s. 52.

59 Spekuluje się, że efekt przebudowy jest wynikiem uproszczenia i przepracowania powstałych dziesięć lat wcześniej projektów, zob. Börsch-Supan, Ostrowska-Kębłowska, Karl Friedrich Schinkel..., s. 84; zob. także: Von Lorck, Schinkels Anbau..., s. 650.

60 Pewnym jest, że wspomniany projekt powstał w Berlińskiej Wyższej Deputacji Budowlanej, zob. „Danziger Dampfboot”, 7.11.1840, s. 1085.

${ }_{61}$ Spośród kilku przedstawień stanu sprzed przebudowy należy wymienić obraz Alberta Wilhelma Juchanowitza z 1839 r. (w zbiorach Kolekcji Malarstwa Muzeum Narodowego w Gdańsku, sygn. MNG/SD/368/M), oddający stan elewacji już po rozpoczęciu prac rozbiórkowych aneksów, a także rysunek inwetaryzacyjny sporządzony przez Helda w 1823 r., zob. APG, Akta Miasta Gdańska 1520-1942, sygn. 16/953, Gdańsk, Dwór Artusa, oraz zachowane w Muzeum Narodowym w Gdańsku rysunki, np. autorstwa Domenico il Quaglio z lat dwudziestych XIX w., sygn. MNG/SD/659/R, drugi sygnowany F. H. z datą 1841, sygn. MNG/ SD/284/R). Z kolei stan po przebudowie uwiecznia np. rysunek Gregoroviusa z 1844 r. (sygn. MNG/SSD329/R) czy sygnowany J.R. z 1848 r. (sygn. MNG/ SD/423/R). Zmiany obu elewacji Dworu Artusa opisuje Jakub Lewicki, Fasady Dworu Artusa w Gdańsku [w:] Dwór Artusa w Gdańsku. Sztuka i sztuka konserwacji, red. Teresa Grzybkowska, Jolanta Talbierska, Warszawa 2004, s. 53-66. 


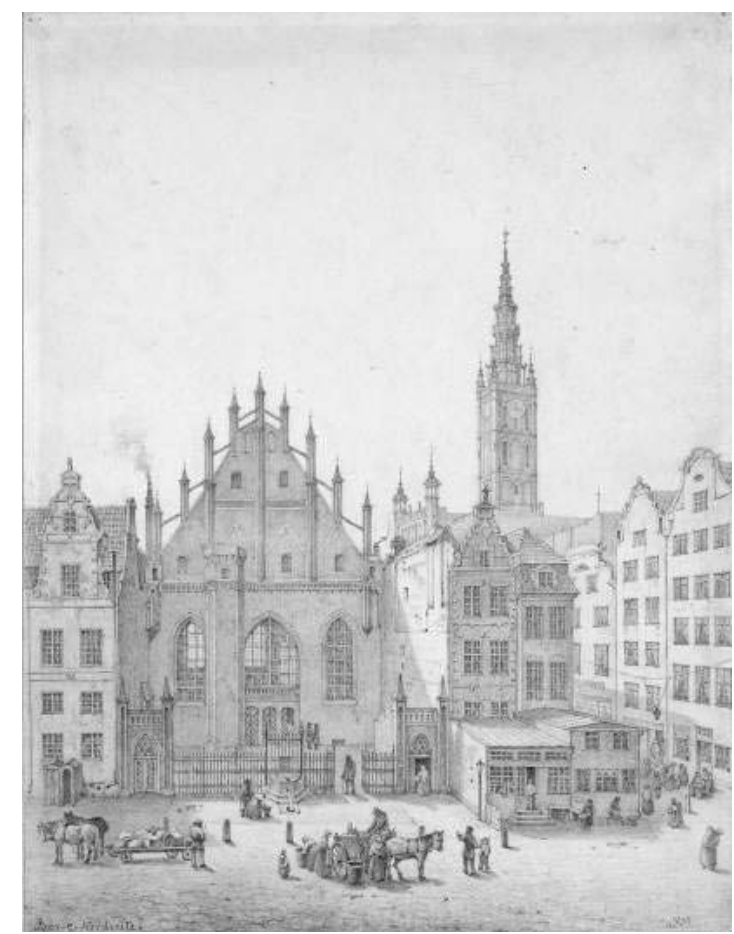

Il. 15. Tylna elewacja Dworu Artusa po przebudowie, 1849, MNG, sygn. MNG/SD/423/R poprzez nadanie im nowej wysokości i zwieńczenie szpiczastymi hełma$\mathrm{mi}^{62}$. Pomysłem projektanta było przebicie pod środkowym oknem trzech otworów wejściowych zamkniętych łukiem odcinkowym (pierwotnie istniało tylko wejście prawe, zachodnie). Wprowadził on także neogotycki fryz pod gzymsem, pod oknem środkowym oraz u zwieńczenia aneksu z klatką schodową. Sam aneks zamiast daszku pulpitowego otrzymał płaskie przekrycie. Z kolei powstały w miejscu dawnych dobudówek dziedziniec odgrodzono od linii ulicy ozdobną kratą, po bokach której zaprojektowano dwie neogotyckie, ceglane bramy ${ }^{63}$. Przybraty one formę zamkniętych ostrołukowo wejść, flankowanych przez dwie wysokie sterczyny. Wykrój szczytów bram oraz kształt sterczyn korespondowały z tymi wieńczącymi elewację $e^{64}$. Z kolei na osi ogrodzenia umieszczono niewielką studnię̨ ${ }^{65}$.

Na początku lat sześćdziesiątych XIX w. Dwór Artusa doczekał się jeszcze jednej modyfikacji. Budowniczy miejski Julius Albert Gottlieb Licht dokonał przebudowy okien fasady budynku, wprowadzając neogotyckie maswerki oraz zegar na osi środkowego okna. Licht był także autorem drewnianego neogotyckiego pawilonu dostawionego przed Dworem i obejmującego Fontannę Neptuna (il. 16). Ta tymczasowa, aczkolwiek efektowna i dosyć kosztowna inwestycja była elementem uroczystej oprawy wizyty króla Wilhelma I z małżonką, którzy odwiedzili Gdańsk 20 października 1861 r. Dwór Artusa został wybrany na miejsce, w którym władze miasta i rejencji podejmowały znamienitych gości ${ }^{66}$. Zarówno aneks, jak i nowa oprawa okien były obce formalnie w stosunku do fasady utrzymanej w stylu północnego renesansu.

${ }^{62}$ Już w 1910 r. podano w wątpliwość zgodność neogotyckich form szczytów z ich pierwotnym kształtem, zob. Schmid, Die Denkmalpflege in Westpreussen..., s. 19.

63 Obie bramy nie zostały odbudowane po zniszczeniach wojennych $1945 \mathrm{r}$. Kształt dziedzińca za budynkiem dworu został uwieczniony na planie z połowy XIX w., zob. APG, Rejencja w Gdańsku, Plany i mapy 1713-1911, sygn. 18/1550, Gdańsk, Dwór Artusa.

64 Por. Karl Gruber, Der Artushof. Eine baugeschichtliche Studie, „Ostdeutsche Monatshefte” 1926, Jg. 7 , H. 6, s. 529.

65 „Danziger Dampfboot”, 22.07.1839, s. 599

66 „Danziger Dampfboot”, 21.10.1861, [s. 2]. 
$\mathrm{W}$ omawianym okresie niewielkie zmiany dosięgły także najbardziej znany z gotyckich zabytków miasta, czyli kościół Mariacki. W 1833 r. odnowiono główne wejście do budyn$\mathrm{ku}^{67}$. W $1862 \mathrm{r}$. poszerzono okno nad portalem i wykonano wokół niego fryz z motywem rozety. Szczególnie warte uwagi są zabiegi, jakim poddano kościół w 1843 r. Z okazji pięćsetnej rocznicy rozpoczęcia budowy kościoła król Fryderyk Wilhelm IV ufundował wymianę trzech okien wschodniej ściany prezbiterium oraz części okien transeptu. Do prac zaangażował nowo powstały Królewski Instytut Witra-

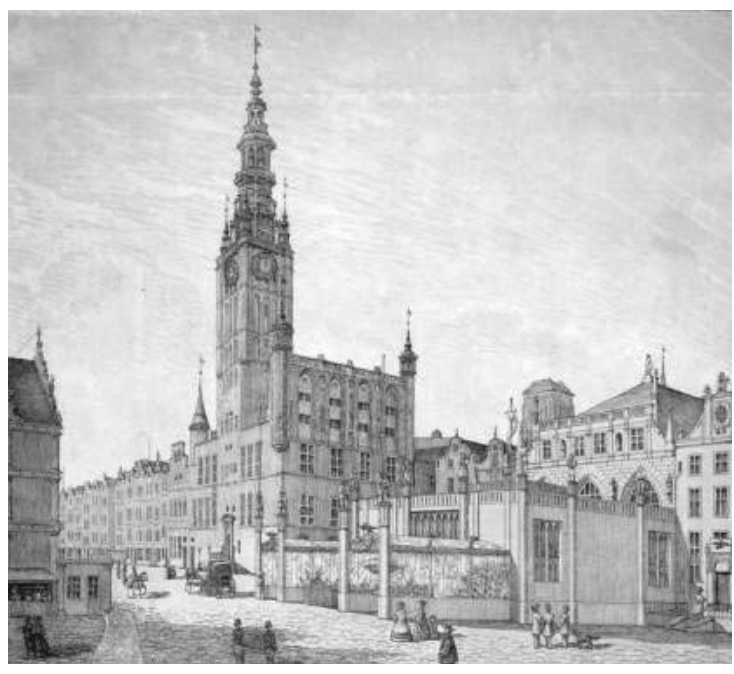

Il. 16. Pawilon przed Dworem Artusa na rycinie J.F. Lorenza, 1861, MNG, sygn. G/625/MPG żowy w Berlinie (Königliches Institut für Glasmalerei) ${ }^{68}$, który dostarczył także projektu samych okien ${ }^{69}$. Pierwotnie pozbawione dekoracji okna otrzymały nowe, neogotyckie, żeliwne maswerki (il. 17). Ich forma odwoływała się do szczególnie istotnej w dobie gotyku symboliki liczby 3. Głównym zadaniem pracowników Instytutu było jednak wyposażenie trzech okien znajdujących się za ołtarzem głównym w witraże. Na centralnym (najszerszym) oknie prezbiterium ukazano przedstawienie pokłonu trzech króli. Karton witrażu sporządził Johann Carl Schultz ${ }^{70}$,

67 Keyser, Die Baugeschichte der Stadt Danzig..., s. 443. Dwa lata później usunięto przylegające do kościoła zabudowania, zob. ibidem, s. 439.

$68 \mathrm{Na}$ czele Instytutu stanął miłośnik sztuki średniowiecznej, generał von Falckenstein, który był również pomysłodawcą wymiany okien w kościele Mariackim. Gdańska realizacja była pierwszym ważnym zleceniem pracowni, która w związku z tym zwiększyła liczbę zatrudnionych artystów, zob. Max Schasler, Berlins Kunstschätze: ein praktisches Handbuch zum Gebrauch bei der Besichtigung derselben, Bd. 2, Berlin 1856, s. 496-497. Zob. także: Eduard Vogel von Falkenstein, Beschreibung des von Seiner Majestät dem Könige im Jahre 1843 gestifteten Haupt-fensters in der Ober-Pfarrkirche in Danzig (Zernecke), „Notizblatt des Architektenvereins zu Berlin" 1844, Jg. 12, Nr. 23-24, s. 130-134.

69 Autorem projektu okien wraz z dekoracją maswerkową był E. von Delitz, zob. Von Falkenstein, Beschreibung des von Seiner Majestät..., s. 133, Bl. 82-84. Przypisanie przez Williego Drosta autorstwa projektu maswerku Johannowi Carlowi Schultzowi wynikało prawdopodobnie z nieznajomości artykułu von Falkensteina, zob. HI, DSHI, 100 Drost 24, St. Marien, s. 65; por. Willi Drost, Die Marienkirche in Danzig und ihre Kunstschätze, b.m.w. 1963, s. 66.

70 Von Falkenstein, Beschreibung des von Seiner Majestät..., s. 133. Schultz był również autorem witraża znajdującego się na jednych z drzwi kościoła, zob. Theodor Hirsch, Die Ober-Pfarrkirche von St. Marien in Danzig in ihren Denkmälern und in ihren Beziehungen zum kirchlichen Leben Danzigs überhaupt, Bd. 1, Danzig 1843, s. 361. Kartony autorstwa Schultza oraz dotyczące witraży gdańskiego kościoła Mariackiego znajdowały się przed wojną w zbiorach 


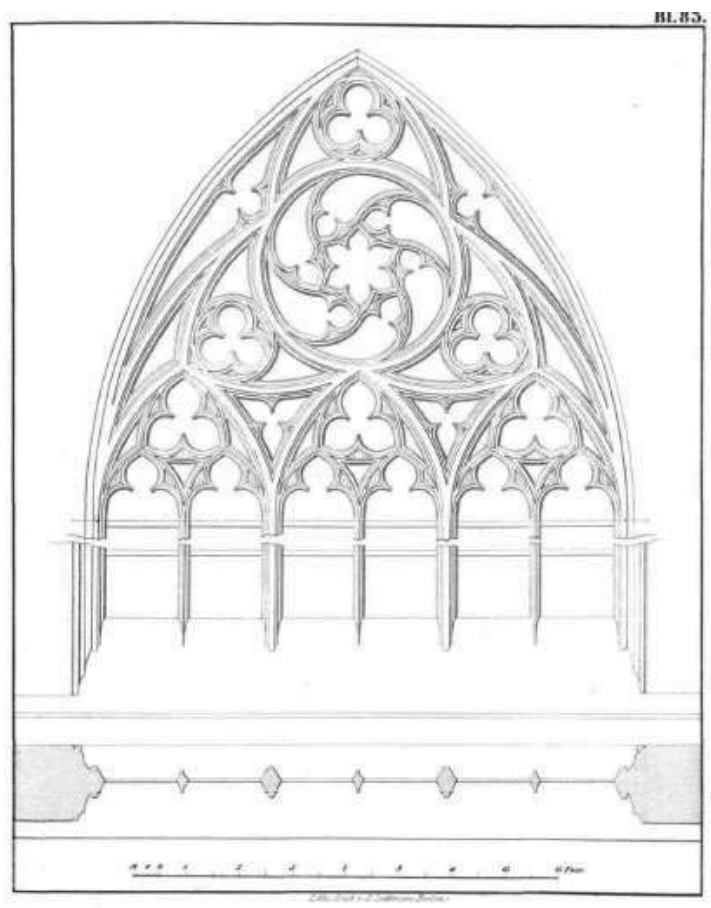

Il. 17. Projekt maswerku dla kościoła Mariackiego, repr. za: „Notizblatt des Architektenvereins zu Berlin” 1844, Nr. 23-24, Bl. 83 wzorując się na przedstawieniu $\mathrm{Ra}$ faela $^{71}$. Pozostałe dwa witraże ukazywały scenę Zwiastowania wzorowaną na pracy Giotta oraz scenę Ofiarowania Jezusa w Świątyni Jerozolimskiej, nawiązującą do obrazu Fra Bartolomeo ${ }^{72}$. Prace nad wymianą okien i wstawianiem witraży były przedsięwzięciem dosyć kosztownym i czasochłonnym $^{73}$. Tworzenie środkowego witrażu o wysokości $19 \mathrm{~m}$ i szerokości $6 \mathrm{~m}$ zajęło 9 miesięcy, a całkowite koszty wymiany okna wyniosły 9500 talarów $^{74}$.

Zakończenie prac nad remontem okien zbiegło się w czasie z ogłoszeniem nowego pomysłu na zmianę wewnątrz budowli. Jej inicjatorem był ówczesny archidiakon kościoła Mariackiego, Theodor Friedrich Kniewel. Wystosował on apel do wiernych o datki, które miały pokryć koszt budowy nowej zakrystii ${ }^{75}$. Planowano, że stanie ona w miejscu starej, ale będzie większa i wyższa. Koszty realizacji inwestycji oszacowano zaledwie na 500 talarów, a oddanie jej do użytku nastąpiło w $1847 \mathrm{r}^{76}$

Nowa zakrystia (il. 18) została wydzielona we wnętrzu kościoła za pomocą trzech niskich ścianek wykonanych z drewna, o bogatej dekoracji snycerskiej

Königlichen Porzellanmanufaktur, obecnie zaginione, zob. Angela Beeskow, Die Ausstattung in den Kirchen des Berliner Kirchenbauvereins (1890-1904). Mit einem Beitrag zur Ikonographie des Protestantismus, Berlin 2005, s. 431, 443.

71 Szczegółowy opis przedstawienia pojawił się na łamach lokalnej prasy, zob. „Danziger Dampfboot”, 30.04.1844, s. 411; „Danziger Dampfboot”, 1.08.1844, s. 734-735.

72 Oba kartony powstały w pracowni malarza Wilhelma Wacha, zob. „Deutsche Kunst-Zeitung", 23.05.1863, s. 166.

73 Przy witrażach pracowało łącznie siedmiu malarzy. Prace na miejscu nadzorował budowniczy miejski Zernecke, zob. Von Falkenstein, Beschreibung des von Seiner Majestät..., s. 130 i nn.

74 Ibidem, s. 132; „Danziger Dampfboot” 20.08.1844, s. 798.

75 APG, Konsystorz Ewangelicki w Gdańsku, sygn. 977/1071, Bauten und Reparaturen an der Oberpfarrkirche Sankt Marien in Danzig, s. 128.

76 Ukończona zakrystia służyła jako registratura, archiwum kościelne oraz miejsce przechowywania cennych naczyń liturgicznych, zob. Agathon Harnoch, Chronik und Statistik der evangelishen Kirchen in den Provinzen Ost- und Westpreussen, Neidenburg 1890, s. 383. 


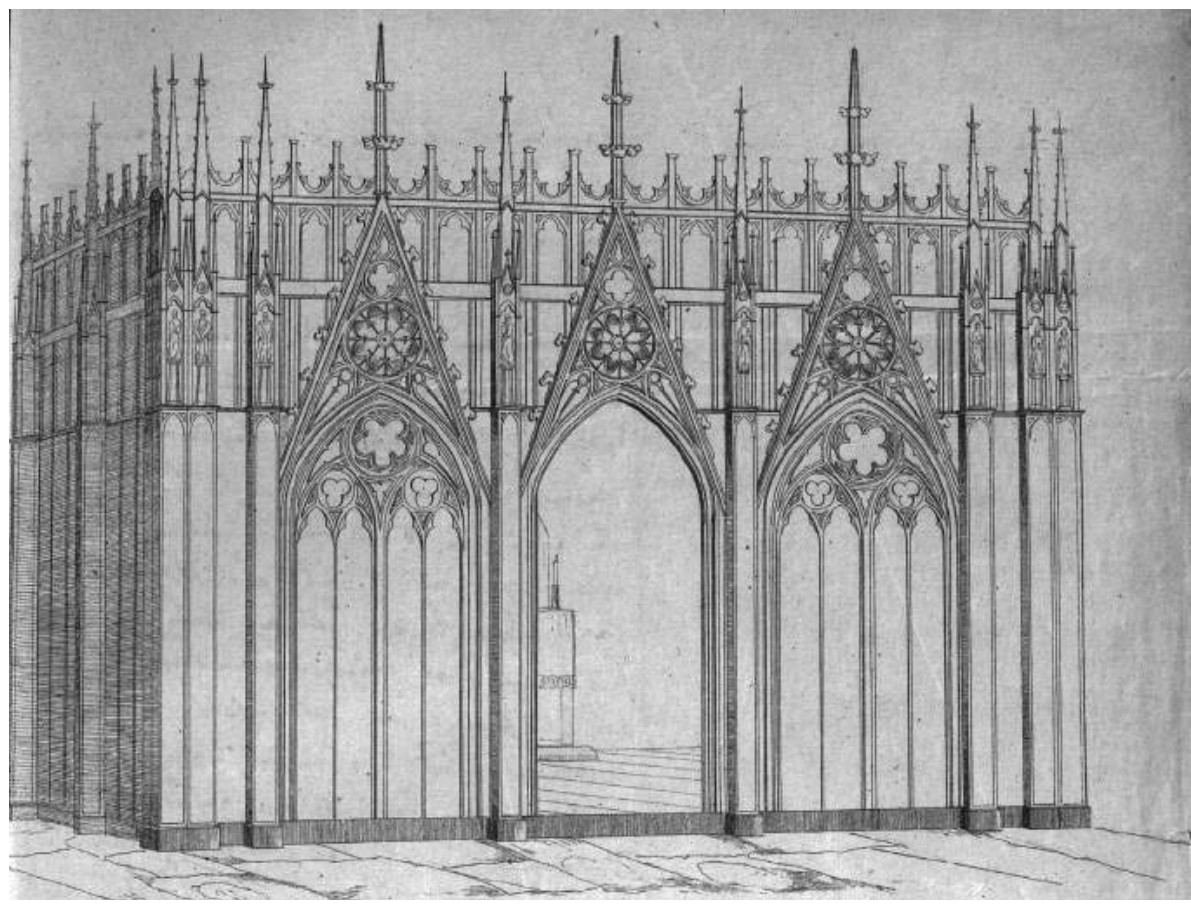

Prze-

kształcenia gdańskich obiektów...

Il. 18. Projekt zakrystii dla kościoła Mariackiego, APG, Konsystorz Ewangelicki w Gdańsku, sygn. akt 977/1071, Bauten und Reparaturen an der Oberpfarrkirche Sankt Marien in Danzig, 1816-1894, k. 128

utrzymanej w neogotyckiej stylistyce. W ściance przedniej umieszczono wejście główne o ostrołukowym zamknięciu. Flankowały je dwie blendy dekorowane ślepymi maswerkami. Wszystkie trzy elementy zostały zwieńczone wimpergami ze zdobieniem w postaci rozet, maswerków, żabek, zakończonych kwiatonami. Ścianki zakrystii zdobiły dodatkowo pinakle. Repertuar zastosowanych motywów był obcy w stosunku do rozwiązań gdańskich, widoczna jest natomiast inspiracja formami gotyckiej katedry w Kolonii.

Podobnie jak kościół Mariacki, wymiany okien doczekał się także inny gdański obiekt sakralny - znajdujący się przy ulicy Długie Ogrody kościół św. Barbary, który od momentu powstania w XV w. przeszedł wiele modyfikacji. Około 1850 r. do okien wybudowanej w pierwszej połowie XVIII w. nawy południowej wstawiono neogotyckie maswerki (il. 19). Nie zrezygnowano przy tym z pierwotnego kształtu wykroju okien o charakterystycznym, półkolistym zamknięciu. W efekcie nowe dekoracje były zupełnie pozbawione typowych dla gotyku ostrych łuków ${ }^{77}$.

Częściowa regotycyzacja dosięgła także znajdujący się na terenie Starego Miasta kościół św. Elżbiety. W 1844 r. władze wojskowe odkupiły tę budowlę

77 HI, DSHI 100 Drost 11, Barbarakirche, s. 4. 


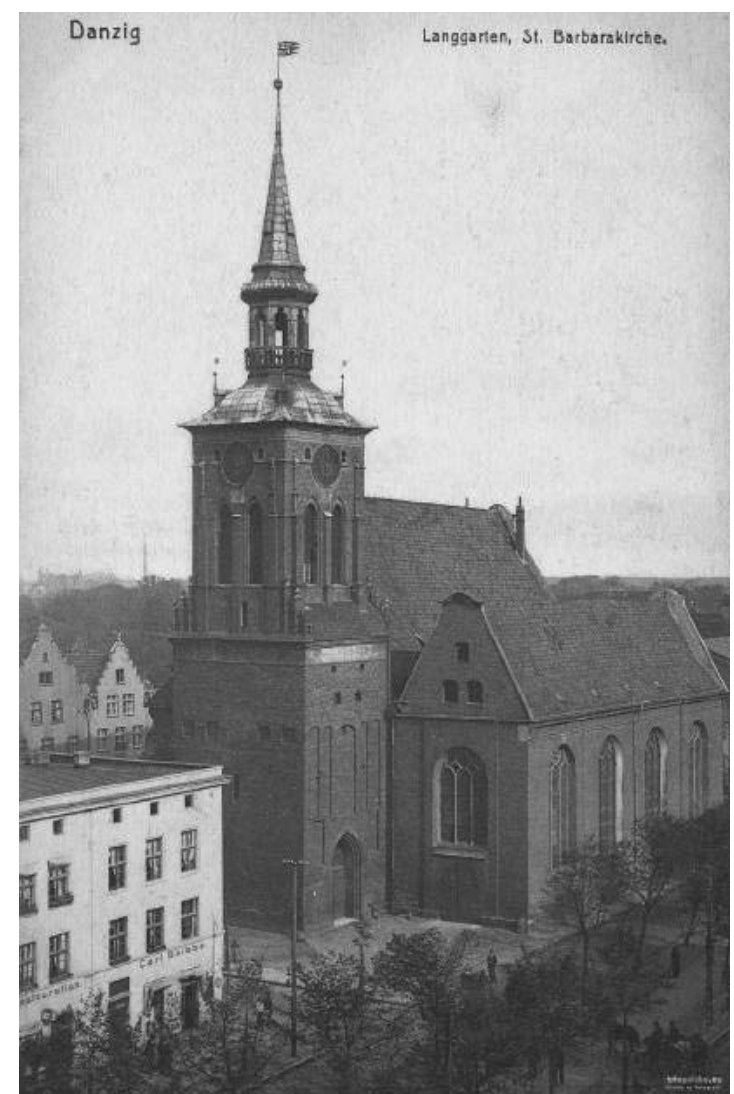

Il. 19. Kościół św. Barbary, stan z początku XX w., fot. zbiory prywatne wraz z leżącym obok szpitalem z przeznaczeniem na ewangelicki kościół garnizonowy. Wkrótce wykonano kapitalny remont ${ }^{78}$, w efekcie którego przebudowano także powstałe w latach 1765-1767 barokowe prezbiterium kościoła, będące wówczas w złym stanie technicznym ${ }^{79}$. Projekt wykonał z ramienia Wyższej Deputacji Budowlanej Friedrich August Stüler, a prace przeprowadzono w latach $1846-1847^{80}$. Kościół pełnił ponownie funkcje sakralne od 24 października 1847 r. Rozwiązaniem zaproponowanym przez Stülera była neogotycka elewacja zwieńczona schodkowym szczytem ze sterczynami (il. 20). Na jej osi architekt zaprojektował dominantę $\mathrm{w}$ postaci wielkiego okna zamkniętego ostrołukowo, z maswerkową dekoracją. Ścianę ozdabiały również otynkowane wewnątrz blendy, powielające kształt wykroju okna. W zwieńczeniu Stüler wprowadził pięć dużych schodków; na ich narożach umieścił czworoboczne sterczyny zwieńczone stożkowymi daszkami z krzyżami.

Rozwiązanie szczytu przypomina inne projekty Stülera, np. kaplicę cmentarną w Krzeszowicach ${ }^{81}$ czy przebudowany według jego projektu kościół Wniebowzięcia NMP w Lipianach.

Spektakularne przebudowy wnętrz budynków w pierwszej połowie XIX w. należały raczej do rzadkości. W zachowanych przekazach omawiany jest tylko jeden wart przytoczenia przykład. Dotyczy on prac, które przeprowadzono przy Ratuszu Głównego Miasta. Znajdująca się na reprezentacyjnym piętrze budynku największa sala (tzw. Wielka Sala Wety, dawne miejsce zebrań Sądu Wetowego

78 Przebudowany został wówczas także budynek szpitala, który od 1844 do 1847 r. pełnił funkcję lazaretu.

79 Dokładny wygląd prezbiterium sprzed przebudowy i jego kształt pierwotny nie są znane.

80 Eva Börsch-Supan, Dietrich Müller-Stüler, Friedrich August Stüler 1800-1865, MünchenBerlin 1997, s. 569. Jako pierwszy informację o autorstwie Stülera podał Erich Keyser, ale pochodzenie tej informacji nie jest znane, zob. idem, Die Baugeschichte der Stadt Danzig..., s. 249.

81 Anna Groth Kubicka, Neogotyckie wielonawowe kościoły Gdańska [w:] Studia nad architekturą Gdańska i Pomorza, red. Andrzej Grzybkowski, Warszawa 2004, s. 161-162. 
oraz Trzeciego Ordynku) została przebudowana przez budowniczego miejskiego Helda już na początku lat dwudziestych na potrzeby obradującej w niej sześćdziesięcioosobowej Rady Miejskiej ${ }^{82}$. Wygląd sali diametralnie zmienił się w 1841 r., kiedy otrzymała ona zupełnie nowy, neogotycki wystrój ${ }^{83}$ (il. 21, 22). Przebudowa była wymuszona pogarszającym się stanem technicznym stropów ${ }^{84}$. Za wzór dla zastosowanego rozwiązania posłużył letni refektarz pałacu Wielkich Mistrzów zamku malborskiego ${ }^{85}$. W wyniku przeprowadzonych zabiegów sala straciła dawne wyposażenie. Podniesiono drewniany, belkowany strop o $120 \mathrm{~cm}$ i wybudowano pod nim neogotyckie sklepienia, wsparte na centralnie ustawionej granitowej kolumnie ${ }^{86}$. Nowe sklepienia otynkowano i pomalowano na biało; to właśnie od tego czasu przyjęła się nowa nazwa sali - Sala Biała (Weißer Saal) ${ }^{87}$. Pracami kierował budowniczy miejski Heinrich Wilhelm Zernecke ${ }^{88}$, a projekt dostarczył pracownik Wyższej Deputacji Budowlanej

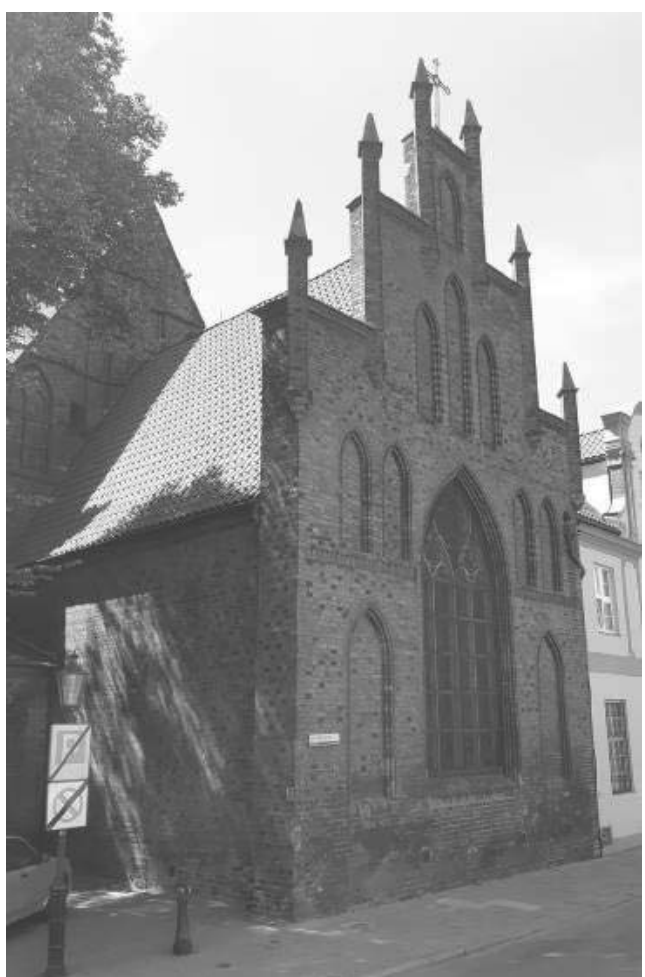

Il. 20. Prezbiterium kościoła św. Elżbiety, stan obecny, fot. Magdalena Staręga Friedrich August Gersdorff (1797-1850), który od 1819 r. aż do swojej śmierci kierował pracami rekonstrukcyjnymi przy malborskim zamku ${ }^{89}$.

Obok szeregu zrealizowanych w pierwszej połowie XIX w. restauracji, w których od lat trzydziestych do głosu zaczęły dochodzić koncepcje purystyczne,

82 Skala oraz efekt przebudowy nie są znane.

83 Pawlowski, Populäre Geschichte..., s. 8. Zob. także: Paul Brandt, Das rechtstädtische Rathaus zu Danzig. Eine baugeschichtliche Studie, Danzig 1909, s. 26, 40. Autor publikacji krytycznie wyraża się o skali tej przebudowy. Podniesiony strop znalazł się na wysokości okien sali znajdującej się nad Salą Białą, por. Karl Hoburg, Geschichte und Beschreibung des Rathhauses d. Rechtstadt Danzigs, Danzig 1857, s. 24-25.

84 „Danziger Dampfboot”, 19.03.1840, s. 272.

85 Arno Schmidt, Führer durch das Rechtstädtische Rathaus, Danzig 1924, s. 16. Zob. także: Schmid, Die Denkmalpflege in Westpreussen..., s. 18-19. Zastosowanie malborskiego wzorca miało wyraźnie ideowe uzasadnienie. Więcej o roli zamku zob. Friedrich, Walka obrazów..., s. 23 i nn.

86 „Danziger Dampfboot”, 30.07.1842, s. 614.

87 Jerzy Kukliński, Das Rechtstädtische Rathaus in Danzig, Gdańsk 1995, s. 17.

88 Schmid, Die Denkmalpflege in Westpreussen..., s. 19.

89 Ibidem. Więcej o karierze urzędnika zob. Bernhard Schmid, Oberpräsident von Schön und die Marienburg, Halle 1940, s. 12-13. 


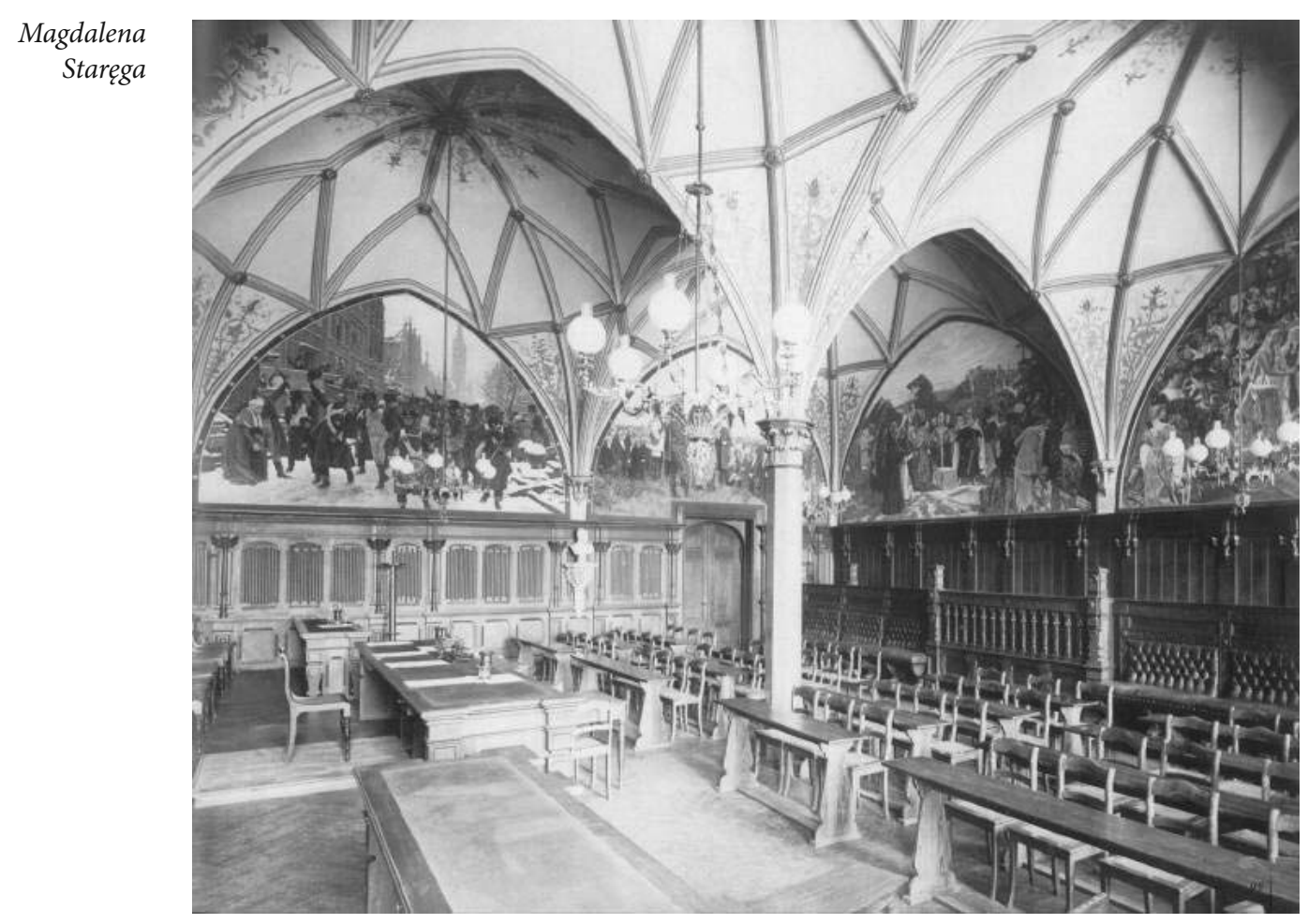

Il. 21. Wielka Sala Wety Ratusza Głównomiejskiego, repr. za: Rudolf Th. Kuhn (1842-1900) fotograf krajobrazu, architektury i morza, red. Jacek Bielak, Gdańsk 2012

należy również wspomnieć o dokonywanych w owym czasie w Gdańsku pracach stricte konserwacyjnych. Miały one na celu naprawę budynku bez dokonywania znaczących zmian w jego pierwotnym kształcie ${ }^{90}$. W 1834 r. odnowiono budynek Wielkiej Zbrojowni, rok później wyremontowano wnętrze kościoła Bożego Ciała, a w 1838 r. wnętrze Kaplicy Królewskiej. Natomiast w 1860 r. przeprowadzono prace renowacyjne Bramy Wyżynnej ${ }^{91}$.

Pierwsza połowa XIX w. to czas stopniowego kształtowania się myśli konserwatorskiej. Świadomość zabytkowej wartości obiektów była początkowo znikoma. Za zabytki uznawano jedynie najważniejsze budowle gotyckie. O znaczeniu danej budowli decydowała na ogół wartość historyczna, nie artystyczna. Tym samym troska o stare budynki nie przejawiała się w dbałości o zachowanie ich oryginalnej formy, koncentrowała się raczej na ich stanie technicznym. Dlatego też dopuszczano daleko idące przebudowy z użyciem nowych form, co nierzadko skutkowało zmianą charakteru budynku.

90 O różnicach między restauracją i konserwacją zob. Edmund Małachowicz, Konserwacja i rewaloryzacja architektury w zespołach $i$ krajobrazie, Wrocław 1994, s. 106-112.

${ }_{91}$ Illustrirter Führer durch Danzig und Umgebungen, Danzig 1861, s. 32, 34, 37, 47. 
Do początku lat trzydziestych XIX w. w Gdańsku dominowały rozwiązania $\mathrm{z}$ wykorzystaniem form klasycystycznych. Stosowano je niezależnie od pierwotnego stylu budynku, tworząc kontrowersyjne $\mathrm{z}$ obecnego punktu widzenia kombinacje stylowe (klasycyzm - gotyk czy klasycyzm - północny renesans). Po okresie największej popularności klasycyzmu w gdańskiej architekturze do głosu zaczęły dochodzić formy neogotyckie, a jednocześnie uznanie gotyku za niemiecki styl narodowy i rozwój myśli konserwatorskiej wyraźnie przełożyło się na wzrost zainteresowania średniowiecznymi zabytkami gdańskimi. Zjawiska te znalazły wyraz w repertuarze form stosowanych przy restauracjach i przebudowach gotyckich budowli. Przeprowadzone $\mathrm{w}$ tym czasie $\mathrm{w}$ ramach regotycyzacji przekształcenia były wyrazem dążenia do zachowania jedności stylowej w zgodzie z panującą ówcześnie doktryną. Nierzadko jednak skala oraz rodzaj przeprowadzonych prac sprawiały, że powstawała forma, która nie przypominała budynku o pierwotnym kształcie.

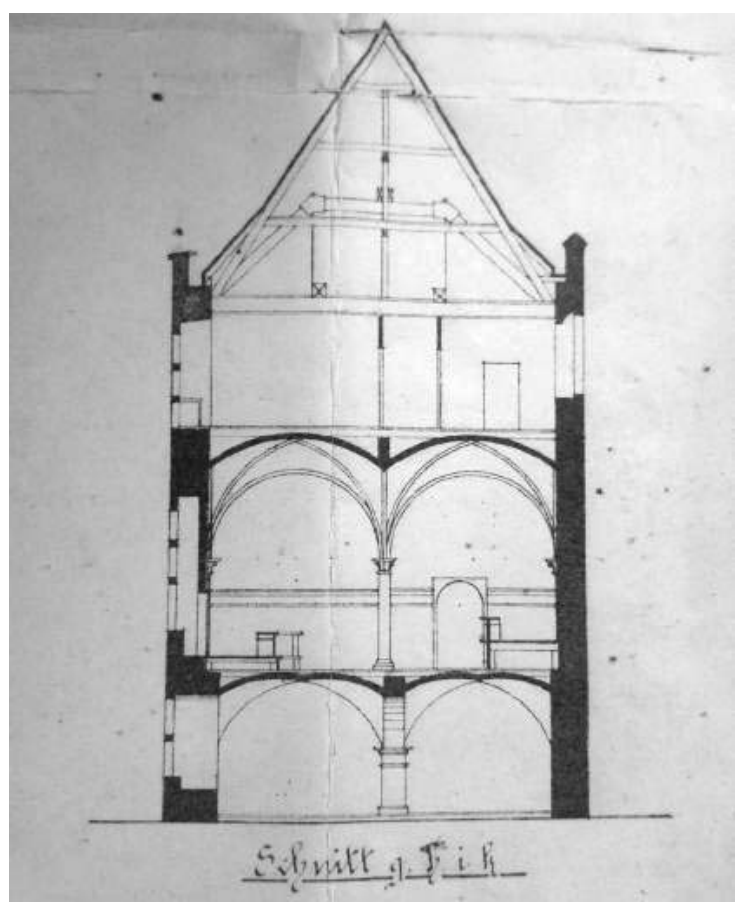

Il. 22. Przekrój południowo-wschodniej części Ratusza Głównomiejskiego z Wielką Salą Wety na pierwszym piętrze, APG, Państwowy Urząd Policji Budowlanej w Gdańsku, sygn. 15/3283, Jopengasse 37, k. 16 Mimo że przeprowadzane wówczas restauracje miały charakter artystycznych kreacji ${ }^{22}$, to z czasem ich twórcy działali w sposób bardziej świadomy - nie tylko dążyli do zachowania danego stylu, lecz także celowo wykorzystywali określone formy ${ }^{93}$.

Wraz ze wzrostem świadomości wartości architektonicznej przebudowanych obiektów w drugiej połowie XIX w., jak i później, dokonano wielu prac przywracających przekształconym już wcześniej gdańskim zabytkom pierwotną formę. Stało się tak w przypadku Bramy Zielonej, która odzyskała dawne szczyty dzięki architektowi miejskiemu Lichtowi w 1886 r. ${ }^{94}$ Wieża kościoła

92 Jerzy Frycz, Neogotyk i restauracja zabytków w Polsce [w:] Sztuka 2 połowy XIX wieku, Warszawa 1973, s. 181.

93 Świadome nawiązania do określonych pierwowzorów, jak np. zamek w Malborku, miały podłoże ideowe. Jacek Friedrich postrzega przeprowadzane od początku XIX w. działania konserwatorskie jako zjawisko silnie zideologizowane, zob. idem, Walka obrazów..., s. 12 i nn.

94 Keyser, Die Baugeschichte der Stadt Danzig..., s. 437, 456; zob. także: Jolanta Barton-Piórkowska, Zielona Brama w Gdańsku. Dzieje i funkcja [w:] Zielona Brama w Gdańsku. Materiały 
Magdalena św. Jakuba w 1881 r. otrzymała hełm pozyskany z rozbiórki bramy św. Jakuba ${ }^{95}$. Starega Dwór Bractwa Św. Jerzego, wraz z przeniesieniem w 1904 r. głównego odwachu do Bramy Wyżynnej został pozbawiony klasycystycznej kolumnady, a dzięki staraniom Stowarzyszenia na rzecz Zachowania Starodawnych Budowli i Zabytków Sztuki Gdańska w 1882 r. odzyskał sygnaturkę ${ }^{96}$. Z kolei w 1888 r. elewacjom Ratusza Staromiejskiego przywrócono częściowo dawny wygląd, usuwając pokrywające je tynki. Przeprowadzona wśród gdańskich kamienic w latach trzydziestych XX w. sanacja objęła również niegdyś klasycystyczne kamienice, którym przywracano pierwotny wygląd, usuwając późniejsze nawarstwienia lub też całkowicie przebudowując fasadę ${ }^{97}$.

Podczas odbudowy Gdańska ze zniszczeń wojennych roku 1945 pomijano $\mathrm{z}$ reguły historyzujące nawarstwienia $\mathrm{z}$ drugiej połowy XIX i pierwszej połowy $\mathrm{XX}$ w. Jako styl graniczny, do którego form powracano, przyjęto klasycyzm ${ }^{98}$. Z tego właśnie powodu do dzisiaj zachowały się przykłady przebudów klasycystycznych z pierwszej połowy XIX w., jak chociażby Brama Świętojańska, którą odbudowano w formach gotycko-klasycystycznych, dzięki czemu stanowi ona ciekawy przykład współistnienia dwóch, zupełnie odmiennych stylów.

\section{Bibliografia}

Arszyński Marian, Działalność Karola Fryderyka Schinkla na ziemiach Pomorza i Wielkopolski, „Zapiski Historyczne” 1984, t. 49, nr 3, s. 51-106.

Arszyński Marian, Idea - pamięć - troska. Rola zabytków w przestrzeni społecznej i formy działań na rzecz ich zachowania od starożytności do połowy XX wieku, Malbork 2007.

Barton-Piórkowska Jolanta, Zielona Brama w Gdańsku. Dzieje i funkcja [w:] Zielona Brama w Gdańsku. Materiały z sesji z 12 maja 2003 w Muzeum Archeologicznym w Gdańsku, red. Janusz Pałubicki, Gdańsk 2004, s. 15-36.

Barylewska-Szymańska Ewa, Gdańskie i lubeckie stowarzyszenia na rzecz ochrony zabytków w XIX i XX wieku [w:] Studia z historii sztuki i kultury Gdańska i Europy Pótnocnej. Prace poświęcone pamięci Doktor Katarzyny Cieślak, red. Jacek Friedrich, Edmund Kizik, Gdańsk 2003, s. 395-416.

Barylewska-Szymańska Ewa, Historia ochrony zabytków architektury w XIX i pierwszych dziesięcioleciach XX w. (do 1945 r.). Zarys problematyki [w:] Rzadzacy i rządzeni. Władza i społeczeństwo od średniowiecza po wspótczesność. Materiały konferencji naukowej zorganizowanej przez Muzeum Historyczne Miasta Gdańska i Stowarzyszenie

z sesji z 12 maja 2003 w Muzeum Archeologicznym w Gdańsku, red. Janusz Pałubicki, Gdańsk 2004, s. 22.

95 Decyzję o przywróceniu hełmu na wieży kościoła podjęto z powodu zbliżającej się wizyty cesarza Wilhelma I, zob. Piwek, Architektura i kościół..., s. 158.

${ }_{96}$ Barylewska-Szymańska, Gdańskie i lubeckie stowarzyszenia..., s. 406.

97 Przykład takich zabiegów stanowiły kamienice przy ulicy Mariackiej 19, 22 czy 32, zob. Volmar, Danzigs Bauwerke..., s. 21.

98 Por. Jacek Friedrich, Odbudowa Gdańska jako miasta polskiego w 1945 roku, „Pomerania” 2007, nr 3, s. 9. 
Rajcy Gdańska w dniach 24 października 2014 r., 29-30 maja 2015 r., red. Sylwia Bykowska, Edmund Kizik, Piotr Paluchowski, Gdańsk 2015, s. 123-146.

Barylewska-Szymańska Ewa, Johann Carl Schultz i ochrona zabytków w Gdańsku [w:] Portret artysty na nowo odkryty. Johann Carl Schultz (1801-1873) znany i nieznany [katalog wystawy], 7 sierpnia - 11 października 2009, red. Justyna Lijka, Malbork 2009, s. $121-142$.

Barylewska-Szymańska Ewa, Maciakowska Zofia, Miasto i ludzie u progu nowoczesności. Socjotopografia Gdańska pierwszej połowy XIX wieku (Studia i materiały do dziejów domu gdańskiego, cz. 4), red. Edmund Kizik, Gdańsk-Warszawa 2016.

Bielak Jacek, Budowniczy Miejski Carl Samuel Held i próby modernizacji Gdańska na przełomie XVIII/XIX wieku [w:] Gdańsk i okolice 1793-1914. Miasto - ludzie - wydarzenia w rysunku i grafice, red. Wojciech Bonisławski, Aleksander Baliński, Gdańsk 2014, s. 56-63.

Börsch-Supan Eva, Müller-Stüler Dietrich, Friedrich August Stüler 1800-1865, MünchenBerlin 1997.

Börsch-Supan Eva, Ostrowska-Kębłowska Zofia, Karl Friedrich Schinkel. Die Provinzen Ost- und Westpreußen und Großherzogtum Posen, München 2003.

Brandstäter August, Chronologische Übersicht der Geschichte Danzigs, Danzig 1879.

Brandt Paul, Das rechtstädtische Rathaus zu Danzig. Eine baugeschichtliche Studie, Danzig 1909.

Bukal Grzegorz, Konserwacja zamku w Malborku jako przykład ksztattowania się doktryny konserwatorskiej, „Ochrona Zabytków” 2008, nr 3, s. 9-92.

Deurer Wolfgang Günter, Danzig. Die Dokumentation 52 historischer Kirchen, Wesel 1996.

Falkenstein Eduard Vogel von, Beschreibung des von Seiner Majestät dem Könige im Jahre 1843 gestifteten Haupt-fensters in der Ober-Pfarrkirche in Danzig (Zernecke), „Notizblatt des Architektenvereins zu Berlin” 1844, Jg. 12, Nr. 23-24, s. 130-134.

Friedrich Jacek, Walka obrazów. Przedstawienia wobec idei w Wolnym Mieście Gdańsku, Gdańsk 2018.

Frycz Jerzy, Neogotyk i restauracja zabytków w Polsce [w:] Sztuka 2 połowy XIX wieku, Warszawa 1973, s. 173-182.

Frycz Jerzy, Restauracja i konserwacja zabytków architektury w Polsce w latach 1795-1918, Warszawa 1975.

Groth Kubicka Anna, Neogotyckie wielonawowe kościoły Gdańska [w:] Studia nad architektura Gdańska i Pomorza, red. Andrzej Grzybkowski, Warszawa 2004, s. 159-213.

Gruber Karl, Der Artushof. Eine baugeschichtliche Studie, „Ostdeutsche Monatshefte” 1926, Jg, 7, H. 6, s. 517-532.

Grzybkowski Andrzej, Schinkla projekt rozbudowy Dworu Artusa w Gdańsku [w:] Artifex doctus. Studia ofiarowane profesorowi Jerzemu Gadomskiemu w siedemdziesiąta rocznicę urodzin, t. 1, red. Wojciech Bałus, Wojciech Walanus, Marek Walczak, Kraków 2007, s. 313-319.

Habela Jadwiga, Ratusz Staromiejski w Gdańsku, Gdańsk 1984.

Habermann Ernst, Westpreußischer Architekten- und Ingenieur-Verein zu Danzig 18601910: Chronik des Vereins zur Feier des 50-jährigen Bestehens, Danzig 1910.

Harnoch Agathon, Chronik und Statistik der evangelishen Kirchen in den Provinzen Ost- und Westpreussen, Neidenburg 1890.

Herrmann Christofer, Rzempołuch Andrzej, Ermländische Ansichten: Ferdinand von Quast und die Anfänge der Denkmalpflege in Preußen und Ermland [Ausstellungskatalog], 
Magdalena Starega

Potsdam 27.04.-2.07.2006, Olsztyn 6 09.-31.10. 2006 = Widoki $z$ Warmii: Ferdynand von Quast i początki konserwatorstwa zabytków w Prusach i na Warmii [katalog wystawy], Potsdam 27.04.-2.07.2006, Olsztyn 6.09.-31.10.2006, Olsztyn 2006.

Hoburg Karl, Geschichte und Beschreibung des Rathhauses d. Rechtstadt Danzigs, Danzig 1857.

Keyser Erich, Denkmalpflege in Danzig vor hundert Jahren, „Denkmalpflege und Heimatschutz" 1926, Nr. 28, s. 54-57.

Keyser Erich, Die Baugeschichte der Stadt Danzig, Köln-Wien 1972.

Kizik Edmund, Omilanowska Małgorzata, Wędrująca kamienica. Kilka uwag o translokacji i skopiowaniu kamienicy gotyckiej przy ulicy Chlebnickiej w Gdańsku w świetle źródeł archiwalnych, „Porta Aurea” 2011, t. 10, s. 80-114.

Krause Waldemar, Das Danziger Theather und sein Erbauer Carl Samuel Held, Danzig 1936.

Kukliński Jerzy, Das Rechtstädtische Rathaus in Danzig, Gdańsk 1995.

Lewicki Jakub, Fasady Dworu Artusa w Gdańsku [w:] Dwór Artusa w Gdańsku. Sztuka i sztuka konserwacji, red. Teresa Grzybkowska, Jolanta Talbierska, Warszawa 2004, s. $53-66$.

Licht Julius Albert Gottlieb, Die Wiederherstellung des ehemaligen Franziskaner-Klosters in Danzig, „Notizheft des Westpreussißchen Architekten- und Ingenieur- Verein” 1877, Nr. 1, s. 23-28.

Lorck Carl von, Schinkels Anbau für den Danziger Artushof, „Ostdeutsche Monatshefte” 1936, Jg. 16, H. 11, s. 647-653.

Löschin Matthias Gotthilf, Danzig und seine Umgebungen, Danzig 1836.

Makała Rafał, „Neorenesans pótnocny” jako niemiecki styl narodowy na przełomie XIX i XX w. [w:] Recepcja renesansu w XIX i XX wieku. Materiały Sesji Stowarzyszenia Historyków Sztuki, Łódź, listopad 2002, red. Małgorzata Wróblewska-Markiewicz, Łódź 2003, s. 307-314.

Małachowicz Edmund, Konserwacja $i$ rewaloryzacja architektury $w$ zespołach i krajobrazie, Wrocław 1994.

Meyer Hans Bernhard, Hundert Jahre Kunstverein zu Danzig 1835-1935, Danzig 1935.

Opaska Janusz, U źródeł ochrony zabytków: rozwój systemowego konserwatorstwa w Niemczech w początkach XIX w., „Ochrona Zabytków” 2010, nr 1-4, s. 199-210.

Pawlowski Josef Nikodemus, Populäre Geschichte Danzig's. Zweiter Theil Beschreibung der hervorragendsten öffentlichen Gebäude Danzigs. Zweiter Abschnitt, Danzig 1883.

Pelczar Maria, Kościót św. Jakuba - Bibliotekq Miejska [w:] Szpital i kościół św. Jakuba. 600 lat fundacji gildii szyprów w Gdańsku, red. Adam Sroka, Toruń 2009, s. 241-259.

Piwek Aleksander, Architektura i kościół św. Jakuba w Gdańsku [w:] Szpital i kościół św. Jakuba. 600 lat fundacji gildii szyprów w Gdańsku, s. 125-166.

Staniszewski Arkadiusz, Fara gdańskiego przedmieścia. Przegląd ikonografii i spojrzenie na architektoniczne dzieje kościoła św. św. Piotra i Pawła w Gdańsku, Gdańsk 2015.

Stankiewicz Jerzy, Szermer Bohdan, Gdańsk. Rozwój urbanistyczny i architektoniczny oraz powstanie zespołu Gdańsk-Sopot-Gdynia, Warszawa 1959.

Schmid Bernhard, Die Denkmalpflege in der Provinz Westpreußen im Jahre 1914, Danzig 1915.

Schmid Bernhard, Die Denkmalpflege in Westpreussen 1804-1910, Danzig 1910.

Schmid Bernhard, Oberpräsident von Schön und die Marienburg, Halle 1940.

Schmidt Arno, Führer durch das Rechtstädtische Rathaus, Danzig 1924.

Szarszewski Adam, Szpital i kościół św. Jakuba w Gdańsku, Zarys historyczny, Toruń 2000 . 
Volmar Erich, Danzigs Bauwerke und ihre Wiederherstellung, Danzig 1940.

Prze-

Zernecke Wilhelm Ferdinand, Cały Gdańsk za dwadzieścia srebrnych groszy. Najnowszy przewodnik po Gdańsku i jego okolicy. Alfabetycznie ułożony opis wszystkiego, co w Gdańsku i okolicy jest godne uwagi lub w jakikolwiek sposób interesujące, tłum. Roman Kowald kształcenia gdańskich obiektów... i Aleksander Masłowski, Gdańsk 2010 (oryg. Danzig 1843).

Żydowicz Marek, Przebudowa średniowiecznego klasztoru pofranciszkańskiego w Gdańsku jako przyczynek do XIX-wiecznej problematyki konserwatorskiej Prus, „Acta Universitatis Nicolai Copernici. Nauki Humanistyczno-Społeczne. Zabytkoznawstwo i Konserwatorstwo" 1989, t. 13, s. 93-119.

\section{Modifications in Gdan'sk's Historic Buildings in the First Half of the $19^{\text {th }}$ century in the Context of Emerging conservational thought}

The article discusses modifications in antique structures of Gdańsk in the first half of the $19^{\text {th }}$ century. The exact time frame for the phenomenon explored is marked by the seizure of the city by the Kingdom of Prussia as a result of the Second Partition of Poland in 1793, and the early 1860s. It was a highly difficult period in the history of Gdańsk. Terrible economic situation resulted in an extremely small number of new, important architectonic projects being implemented. Instead, the authorities began adapting old buildings to new needs, often not without significant alterations. Other major modifications to historic structures were introduced in the course of repairs and reconstructions of deteriorated and war-damaged buildings.

The first half of the $19^{\text {th }}$ century is a time which saw a substantial change in the perception of historic sites and their value. The article highlights the occurrence of this process in Gdańsk. Reconstructions involving classicist stylistic forms, which gave way to the coexistence of old and new formal marks, as well as later ones, introduced in the course of regothicisation, characterised by aiming at stylistic cohesion are examined.

The modifications extended to many of Gdańsk's most important historic buildings. Architects such as Karl Friedrich Schinkel or Friedrich August Stüler were involved in the discussed process. The number and extent of undertaken redevelopments indicates that they constitute a significant aspect of the $19^{\text {th }}$-century Gdańsk architecture. 